\title{
SPATIOTEMPORAL VARIABILITY IN TREE GROWTH IN THE CENTRAL PYRENEES: CLIMATIC AND SITE INFLUENCES
}

\author{
Jacques Tardif, ${ }^{1}$ Jesús Julio Camarero, Montse Ribas, and Emilia Gutiérrez
}

Universitat de Barcelona, Department d'Ecologia, Facultat Biologia, Diagonal 645, 08028 Barcelona, Catalunya, Spain

\begin{abstract}
To understand how tree growth has responded to recent climate warming, an understanding of the tree-climate-site complex is necessary. To achieve this, radial growth variability among 204 trees established before 1850 was studied in relation to both climatic and site factors. Seventeen forest stands were sampled in the Spanish Central Pyrenees. Three species were studied: Pinus uncinata, Abies alba, and Pinus sylvestris. For each tree, a ring-width residual chronology was built. All trees cross-dated well, indicating a common influence of the regional climate. For the 1952-1993 period, the radial growth of all species, especially $P$. uncinata, was positively correlated with warm Novembers during the year before ring formation and warm Mays of the year the annual ring formed. Differences in species-stand elevation modulated the growth-climate associations. Radial growth in $P$. uncinata at high elevation sites was reduced when May temperatures were colder and May precipitation more abundant. In the 20th century, two contrasting periods in radial growth were observed: one (1900-1949) with low frequency of narrow and wide rings, low mean annual sensitivity, and low common growth variation; and another (19501994) with the reverse characteristics. The increased variability in radial growth since the 1950s was observed for all species and sites, which suggests a climatic cause. The low shared variance among tree chronologies during the first half of the 20th century may result from a "relaxation" of the elevation gradient, allowing local site conditions to dominate macroclimatic influence. These temporal trends may be related to the recently reported increase of climatic variability and warmer conditions. This study emphasizes the need to carefully assess the relationships between radial growth and site conditions along ecological gradients to improve dendroclimatic reconstructions.
\end{abstract}

Key words: Abies alba; climate change; dendroecology; mean sensitivity; Pinus sylvestris; Pinus uncinata; Principal Component Analysis (PCA); radial growth; Redundancy Analysis (RDA); response function; site factors.

\section{INTRODUCTION}

Recent studies of worldwide meteorological data from high elevation stations have shown that air temperature has increased during this century for most areas (Diaz and Bradley 1997). This is consistent with worldwide trends in surface temperature data (Folland et al. 1990, Jones 1994, Houghton et al. 1996). Diaz and Bradley (1997) reported a strong warming trend for Western Europe starting in the 1940s and resulting in the most recent decades being warmer than any other period in the instrumental record. Temperature records from the Pic du Midi in the Central Pyrenees registered a mean annual temperature increase of $0.83^{\circ} \mathrm{C}$ between 1882 and 1970 (Bücher and Dessens 1991). The greatest warming was observed in the mean monthly minimum temperatures, whereas the mean monthly maximum temperatures decreased slightly during the same period producing an overall decrease in the monthly

Manuscript received 27 June 2001; revised 14 March 2002; accepted 1 April 2002; final version received 24 April 2002. Corresponding Editor: S. T. Jackson.

${ }^{1}$ Present address: Centre for Forest Interdisciplinary Research (C-FIR), University of Winnipeg, 515 Avenue Portage, Winnipeg, Manitoba, Canada R3B 29E.

E-mail: j.tardif@uwinnipeg.ca thermal amplitude. A mean warming of $\sim 1^{\circ} \mathrm{C}$ in the 1980s has been described in the Alps with a clear increase in the mean monthly minimum temperatures (Beniston et al. 1997, Rolland et al. 1998).

A precise understanding of the climatic characteristics for mountain regions with complex topography is, however, complicated by the lack of observational data at a spatial and temporal resolution adequate for climate research (Beniston et al. 1997). In mountain regions, General Circulation Models have poor applicability and resolution (Guisan et al. 1995). Climatic studies in these remote areas must rely on proxy records of past climates because instrumental records are generally short (Beniston et al. 1997). In high elevation forests, climate constitutes the main limiting factor for tree growth (Tranquillini 1979, Hansen-Bristow 1986, Grace and Norton 1990). High elevation forests are exceptional for the potential they offer for climate reconstruction and the assessment of the impact of climate change on ecosystems. Annual tree ring series can provide high resolution proxy records to assess environmental changes that have occurred over recent centuries (Luckman 1990, Villalba et al. 1994, 1997, Tessier et al. 1997).

In mountain environments, climatic conditions and growth characteristics are strongly influenced by ele- 
vation (Hansen-Bristow 1986, Kienast et al. 1987, Rolland et al. 1999). However, local climate can be modified by site factors such as slope, aspect, and degree of exposure to wind even at the same elevation (Barry 1992). A better understanding of the interactions between site conditions and climate is necessary to disentangle the tree-climate-site complex (Hughes et al. 1978, Villalba et al. 1994, Tessier et al. 1997). The main objective of this study was to assess the influence of climate and site conditions on ring-width chronologies from individual trees. To do so, a network of tree ring chronologies was developed for the National Park of Aiguiestortes and Estany de Sant Maurici and its buffer zone, the Spanish Central Pyrenees.

Our first objective was to identify the principal climatic factors influencing the radial growth of three dominant conifer species in the Central Pyrenees ( $P i$ nus uncinata Ram., Pinus sylvestris L., Abies alba Mill.). Our second objective was to assess how the climate-growth associations of individual trees were influenced by variations in site factors. This would permit a better understanding of the impact of future climatic change in spatially heterogeneous environments such as mountains. In the absence of long-term meteorological data for the region, our third objective was to document climatic stability at different time periods by quantifying the temporal stability of similarity in ring-width variation among tree chronologies. We hypothesized that similarity among chronologies should decrease under less limiting climatic conditions, whereas it should increase under less favorable climatic conditions. Our final objective was to take advantage of the Pic du Midi meteorological data to assess how changes in monthly mean temperatures may have affected radial growth of $P$. uncinata since the end of the 19 th century.

\section{METHODS \\ Study area}

The Aigüestortes and Estany de Sant Maurici National Park $\left(42^{\circ} 35^{\prime} \mathrm{N}, 00^{\circ} 57^{\prime} \mathrm{E}\right)$ is located in the Spanish Central Pyrenees, western Catalan Pyrenees, Province of Lleida (Fig. 1). The park, created in 1955, covers an area of $\sim 14119$ ha. Most of the National Park is located on granites or granodiorites (Ventura 1992), which form the main geological substrate in the Axial Pyrenees. These bedrocks generate mainly acidic soils.

The Spanish Pyrenees form a biogeographic strip in which eurosiberian species are dominant, in contrast to the nearby Ebro Basin, where most species show Mediterranean affinities. The altitudinal zonation of vegetation in the Spanish Pyrenees is well established (Vigo and Bonada 1976, Vigo and Ninot 1987, Carrillo and Ninot 1992). In the montane altitudinal belt, $A$. alba forms mesic forests accompanied by Fagus sylvatica $\mathrm{L}$. These are especially well developed on slopes with an N-NW aspect (1000-1600 m above sea level).
Abies alba intermingles with $P$. uncinata in subalpine forests $(1600-2000 \mathrm{~m})$. The understory of this community may contain montane (e.g., Sanguisorba minor Scop. subsp minor) and typical subalpine species (Rhododendron ferrugineum L., Vaccinium myrtillus L.). Pinus sylvestris is dominant in the upper montane belt, above lower submediterranean oak forests. These forests are in contact with the lower subalpine forests, mainly in S aspects (1200-1900 m). These xeric communities are developed on poor and unstable soils, where pioneer species are usually found (e.g., Juniperus communis L.).

Pinus uncinata is a shade-intolerant tree species whose distribution in Spain is limited to the subalpine forests of the Pyrenees (1600-2500 m) and to two isolated populations in the Iberian System (Ceballos and Ruiz de la Torre 1979). This species constitutes the main component of the upper forest limits and tree lines in the Pyrenees (Cantegrel 1983, Gil Pelegrín and Villar Pérez 1988, Carreras et al. 1996). On acidic soils, this forest type is characterized by shrubs and several secondary tree species (Salix caprea L., Sorbus aucuparia L., Betula spp.). On southern aspects and on acidic soils, xerophilous (J. communis subsp. alpina (Suter) Celak) or acidophilous species (Festuca eskia Ram. ex DC. in Lam. \& DC.) are frequently observed in the understory (Vigo and Bonada 1976, Vigo and Ninot 1987, Carrillo and Ninot 1992). Previous studies revealed the presence of $P$. uncinata $>600$ years old at 2300-2400 m a.s.1. in this region (Creus 1991-1992, Creus et al. 1992). Pinus uncinata intermingles with P. sylvestris at $1200-1900 \mathrm{~m}$ in areas of the Pyrenees with continental climates, and intermingles with $A$. alba at 1000-2000 $\mathrm{m}$ in mesic sites (Ceballos and Ruiz de la Torre 1979, Gómez Manzaneque 1997).

The macroclimate of the Pyrenees is strongly influenced by its east-west alignment between the Mediterranean Sea and the Atlantic Ocean (Del Barrio et al. 1990). The extreme western part of the region falls under the influence of the Atlantic and is characterized by cyclonic precipitation and relatively small differences between summer and winter temperature. This oceanic influence decreases eastward until the typical Mediterranean conditions prevail (e.g., warm and dry summer). The Central Pyrenees, distant from both bodies of water, experience more continental conditions (Del Barrio et al. 1990). The climate of our study area is continental with some oceanic influence. Local meteorological stations (Bonaigua, $\sim 10 \mathrm{~km}, 2263 \mathrm{~m}$, $42^{\circ} 40^{\prime} \mathrm{N}, 01^{\circ} 00^{\prime} \mathrm{E}$; Estany Gento, $\sim 11 \mathrm{~km}, 2174 \mathrm{~m}$, $42^{\circ} 30^{\prime} \mathrm{N}, 01^{\circ} 01^{\prime} \mathrm{E}$ ) have recorded a mean annual temperature of $3.0^{\circ} \mathrm{C}$ and a total annual precipitation of $\sim 1200 \mathrm{~mm}$ (Plana 1985, Allué 1990). At Bonaigua, the warmest and the coldest months were July (mean of $11^{\circ} \mathrm{C}$ ) and January (mean of $-3.3^{\circ} \mathrm{C}$ ), respectively. The prevailing wind direction is from the W-NW. 


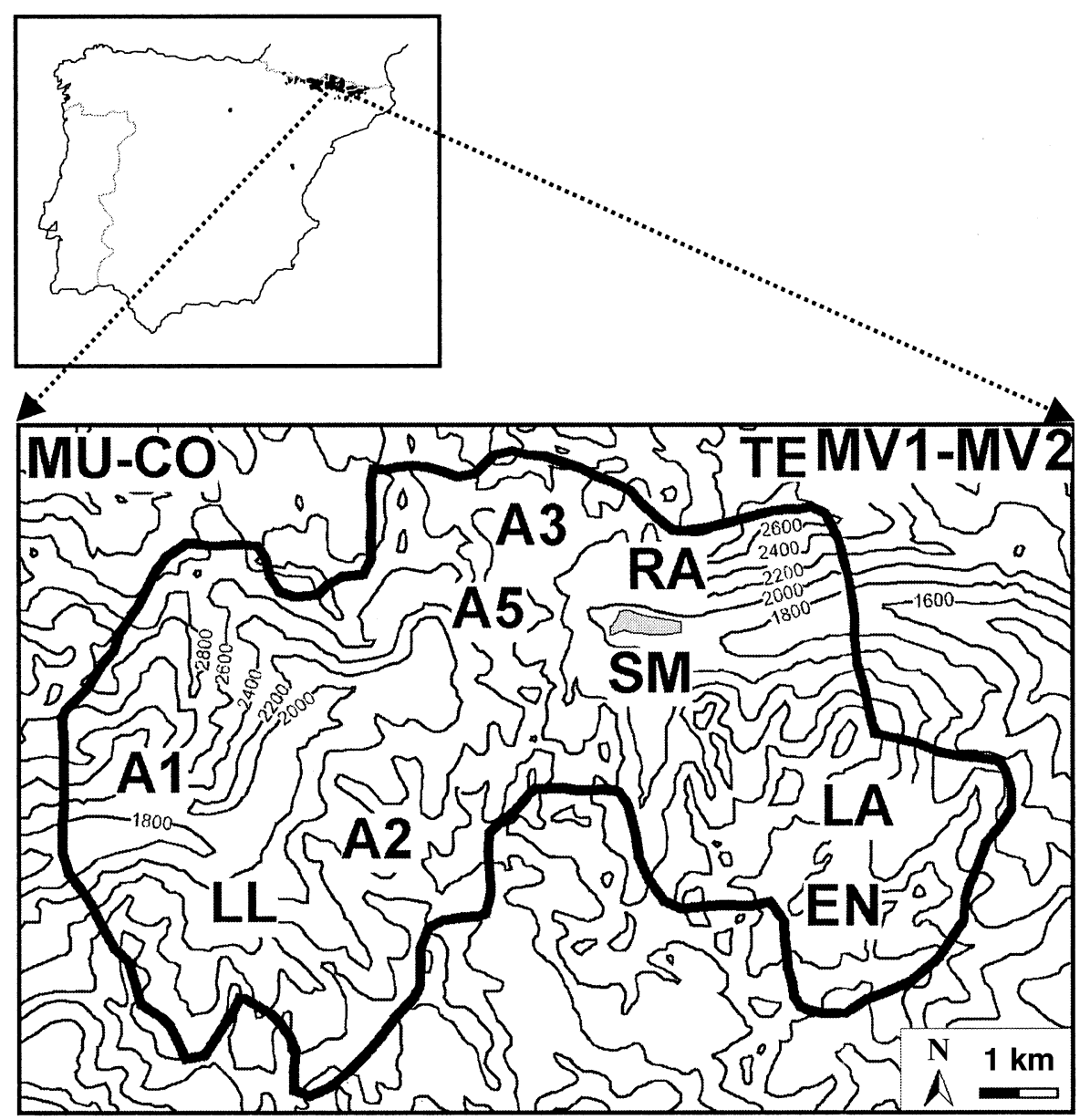

FIG. 1. Topographic map of the Aigüestortes i Estany de Sant Maurici National Park (larger map: area delineated by the thick line) and its approximate location in the Spanish Pyrenees (smaller figure: black areas correspond to the distribution of Pinus uncinata on the Iberian Peninsula) showing the location of sampled stands. Chronology codes are as in Table 1. The elevation interval between contour lines is $200 \mathrm{~m}$. The Sant Maurici lake is shown with gray fill near SM site.

\section{Data collection}

Seventeen forest stands were sampled at different elevations and locations within the National Park. Three species were studied: $P$. sylvestris (1 site), $A$. alba (4 sites), and $P$. uncinata (12 sites). The sampling was conducted to find old forest stands lacking evidence of disturbance such as logging, insect outbreaks, or large-scale blowdown. For each stand, 1 to 3 cores were taken from 10 or more dominant trees (except for Serrader site, $P$. uncinata, code A1 in Table 1) at $\sim 1.3$ $\mathrm{m}$ using an increment borer. For some trees, only one core was taken due to heart rot. For each tree, size (height and diameter at $1.3 \mathrm{~m}$ ), vital status, topographic position, edaphic characteristics, and nearby floristic composition were recorded.

The geographical and ecological characteristics of the 17 stands are presented in Table 1. All stands were located between 1600 and $2370 \mathrm{~m}$ a.s.l. Those of $P$. uncinata grew on high elevation sites that were characterized by well-drained, sparse soil. At a higher el- evation, $P$. uncinata was usually characterized by smaller stature and a loss of apical dominance. In contrast, trees of $P$. uncinata, $P$. sylvestris, and A. alba at lower elevation possessed a conical form and grew in denser forests. Abies alba occupied some of the lowest elevations and more mesic sites (North aspect). These trees were amongst the tallest and the fastest growing.

\section{Data analysis}

For each site, the cores were prepared following the standard dendrochronological techniques (Stokes and Smiley 1968). All samples were dated and visually cross-dated to detect the presence of either false or incomplete rings, which were only rarely encountered. After cross-dating, all cores were measured to a precision of $0.01 \mathrm{~mm}$ using the Aniol-CATRAS measuring system (Aniol 1983). Cross-dating was further validated using the program COFECHA, which calculates cross correlations between individual series and a reference chronology (Holmes 1983). Series showing por- 
TABLE 1. Ecological characteristics for each of the sampled sites.

\begin{tabular}{lrlccccccc}
\hline \hline \multicolumn{1}{c}{ Site } & & & & & & & & $\begin{array}{c}\text { Age at } \\
\text { coring } \\
\text { height (yr) }\end{array}$ \\
\hline Serrader & 11 & A1 & $P s$ & $42^{\circ} 33^{\prime} \mathrm{N}$ & $0^{\circ} 54^{\prime} \mathrm{E}$ & $\mathrm{S}-\mathrm{SE}$ & $1874 \pm 66$ & $27 \pm 12$ & $233 \pm 34$ \\
Conangles & 14 & $\mathrm{CO}$ & $\mathrm{Aa}$ & $42^{\circ} 38^{\prime} \mathrm{N}$ & $0^{\circ} 45^{\prime} \mathrm{E}$ & $\mathrm{N}-\mathrm{NW}$ & $1707 \pm 79$ & $26 \pm 5$ & $259 \pm 40$ \\
Mulleres & 12 & $\mathrm{MU}$ & $\mathrm{Aa}$ & $42^{\circ} 38^{\prime} \mathrm{N}$ & $0^{\circ} 44^{\prime} \mathrm{E}$ & $\mathrm{N}-\mathrm{NE}$ & $1763 \pm 88$ & $34 \pm 13$ & $256 \pm 67$ \\
Mata València & 9 & $\mathrm{MV} 2$ & $\mathrm{Aa}$ & $42^{\circ} 38^{\prime} \mathrm{N}$ & $1^{\circ} 04^{\prime} \mathrm{E}$ & $\mathrm{N}-\mathrm{NE}$ & $1766 \pm 10$ & $12 \pm 5$ & $220 \pm 21$ \\
Mata València & 4 & $\mathrm{MV} 1$ & $\mathrm{Aa}$ & $42^{\circ} 38^{\prime} \mathrm{N}$ & $1^{\circ} 04^{\prime} \mathrm{E}$ & $\mathrm{N}-\mathrm{NE}$ & $2008 \pm 48$ & $20 \pm 5$ & $208 \pm 32$ \\
Sant Maurici & 19 & $\mathrm{SM}$ & $P u$ & $42^{\circ} 35^{\prime} \mathrm{N}$ & $1^{\circ} 00^{\prime} \mathrm{E}$ & $\mathrm{S}-\mathrm{SE}$ & $1933 \pm 5$ & $16 \pm 15$ & $173 \pm 11$ \\
Serrader & 1 & $\mathrm{~A} 1$ & $P u$ & $42^{\circ} 33^{\prime} \mathrm{N}$ & $0^{\circ} 54^{\prime} \mathrm{E}$ & $\mathrm{E}-\mathrm{SE}$ & $1970 \pm 0$ & $30 \pm 0$ & $188 \pm 0$ \\
Mata València & 5 & $\mathrm{MV} 1$ & $P u$ & $42^{\circ} 38^{\prime} \mathrm{N}$ & $1^{\circ} 04^{\prime} \mathrm{E}$ & $\mathrm{N}-\mathrm{NW}$ & $2019 \pm 7$ & $19 \pm 10$ & $221 \pm 70$ \\
Emb. Lladres & 10 & $\mathrm{LA}$ & $P u$ & $42^{\circ} 33^{\prime} \mathrm{N}$ & $1^{\circ} 04^{\prime} \mathrm{E}$ & $\mathrm{N}-\mathrm{NW}$ & $2076 \pm 17$ & $36 \pm 21$ & $392 \pm 129$ \\
Conangles & 17 & $\mathrm{CO}$ & $P u$ & $42^{\circ} 38^{\prime} \mathrm{N}$ & $0^{\circ} 45^{\prime} \mathrm{E}$ & $\mathrm{S}-\mathrm{SW}$ & $2106 \pm 180$ & $43 \pm 15$ & $324 \pm 96$ \\
Barranc de Llacs & 35 & $\mathrm{LL}$ & $P u$ & $42^{\circ} 43^{\prime} \mathrm{N}$ & $0^{\circ} 55^{\prime} \mathrm{E}$ & $\mathrm{N}-\mathrm{NW}$ & $2120 \pm 65$ & $44 \pm 30$ & $466 \pm 192$ \\
El Mirador & 6 & $\mathrm{~A} 5$ & $P u$ & $42^{\circ} 35^{\prime} \mathrm{N}$ & $0^{\circ} 59^{\prime} \mathrm{E}$ & $\mathrm{N}-\mathrm{NE}$ & $2187 \pm 45$ & $43 \pm 38$ & $414 \pm 128$ \\
Delluí-Cortiselles & 19 & $\mathrm{~A} 2$ & $P u$ & $42^{\circ} 34^{\prime} \mathrm{N}$ & $0^{\circ} 57^{\prime} \mathrm{E}$ & $\mathrm{W}-\mathrm{NW}$ & $2208 \pm 82$ & $24 \pm 18$ & $451 \pm 82$ \\
Tessó de Son & 15 & $\mathrm{TE}$ & $P u$ & $42^{\circ} 36^{\prime} \mathrm{N}$ & $1^{\circ} 03^{\prime} \mathrm{E}$ & $\mathrm{N}-\mathrm{NE}$ & $2239 \pm 115$ & $42 \pm 14$ & $225 \pm 43$ \\
Ratera & 5 & $\mathrm{RA}$ & $P u$ & $42^{\circ} 35^{\prime} \mathrm{N}$ & $1^{\circ} 00^{\prime} \mathrm{E}$ & $\mathrm{N}$ & $2300 \pm 0$ & $40 \pm 0$ & $290 \pm 93$ \\
Amitges & 12 & $\mathrm{~A} 3$ & $P u$ & $42^{\circ} 36^{\prime} \mathrm{N}$ & $0^{\circ} 59^{\prime} \mathrm{E}$ & $\mathrm{S}-\mathrm{SE}$ & $2333 \pm 23$ & $32 \pm 18$ & $255 \pm 61$ \\
Estany Negre & 10 & $\mathrm{EN}$ & $P u$ & $42^{\circ} 32^{\prime} \mathrm{N}$ & $1^{\circ} 03^{\prime} \mathrm{E}$ & $\mathrm{N}-\mathrm{NE}$ & $2360 \pm 9$ & $31 \pm 39$ & $261 \pm 60$ \\
\hline
\end{tabular}

Notes: The data in columns 7-14 represent the means \pm 1 SD from trees sampled at each site. The code for each site is the same as in Fig. 1.

$\dagger$ Tree species abbreviations are as follows: Ps $=$ Pinus sylvestris; $A a=$ Abies alba; $P u=$ Pinus uncinata

\$ The annual sensitivity constitutes the relative difference from one ring-width index to the next and is calculated by dividing the absolute value of the differences between each pair of ring-width indices by the mean of the paired index (Fritts 1976).

tions of abnormal growth or low correlation with the reference chronology were either truncated or discarded to minimize the effect of atypical tree ring series on the final chronology. For instance, all series showing strong growth-release effects were split and separately detrended (Blasing et al. 1983).

A chronology was produced for each selected tree since our main objective was to analyze the spatiotemporal variability of radial growth among trees. Only trees established before 1850 were used to maximize the longest time period and the greatest number of trees in the sample. This gave 204 trees (154 P. uncinata, 39 A. alba, and $11 P$. sylvestris). Each ring-width series was standardized using a spline function with a $50 \%$ frequency response of 32 years (Cook and Peters 1981). Standardization involved transforming the ring-width value into a dimensionless index by dividing the observed ring-width values by the expected values given by the spline function (Fritts 1976), which retained high frequency growth variation and filtered out medium to low frequency trends.

We used program ARSTAN (Cook 1985) to standardize all tree ring series. The tree summaries (chronologies) option was selected in ARSTAN. The program uses an arithmetic mean to average the standardized series from the same tree and produces a tree chronology. Most tree chronologies were constructed from two measured radii and, in very few cases, from only one or more than two measured series. Autoregressive modeling was performed on each tree chronology to remove temporal autocorrelation and make each observation independent, a condition necessary for most statistical analyses (Legendre and Legendre 1998). All tree chronologies were autoregressively modeled using the FMT program from the Dendrochronology Program Library (Holmes 1992). A total of 204 tree residual chronologies was developed following this procedure.

\section{Statistical analyses}

Radial growth-climate association.-In dendroecology, the relationships between tree ring indices and climate variables are usually calculated in the form of a correlation or a response function (Fritts 1976, Cook and Kairiukstis 1990). The relationships among individual tree ring chronologies and climate factors were assessed using redundancy analysis (RDA), which is the direct extension of multiple regression applied to multivariate data. RDA, the canonical form of principal component analysis (PCA), is a multivariate "direct" gradient analysis intended to display the main trends in variation of a multidimensional data set in a reduced space of few and linearly independent dimensions (Legendre and Legendre 1998). In RDA, the ordination axes are constrained to be linear combinations of supplied environmental variables (ter Braak and Prentice 1988, ter Braak 1994, ter Braak and Smilauer 1998).

Redundancy analysis is effective in quantifying the relationship between tree ring indices and climatic factors (Beeckman 1992). The decision to use RDA over other canonical methods like canonical correspondence analysis (CCA) was justified because CCA is inappropriate for extremely short gradients (Legendre and Legendre 1998, ter Braak and Smilauer 1998). The good cross-dating among trees, sites, and species indicated that the common macroclimatic signal was coherent for all chronologies over the study area. 
TABLE 1. Extended

\begin{tabular}{|c|c|c|c|}
\hline Height (m) & $\begin{array}{c}\text { Diameter } \\
\text { at breast } \\
\text { height }(\mathrm{cm})\end{array}$ & $\begin{array}{l}\text { Mean radial } \\
\text { growth }(\mathrm{mm})\end{array}$ & $\begin{array}{c}\text { Mean } \\
\text { sensitivity } \ddagger\end{array}$ \\
\hline $10.6 \pm 4.4$ & $65.8 \pm 22.4$ & $1.01 \pm 0.56$ & $0.26 \pm 0.03$ \\
\hline $21.7 \pm 5.0$ & $91.2 \pm 29.5$ & $1.11 \pm 0.40$ & $0.15 \pm 0.02$ \\
\hline $17.4 \pm 2.1$ & $76.1 \pm 23.6$ & $1.26 \pm 0.52$ & $0.16 \pm 0.02$ \\
\hline $21.1 \pm 2.6$ & $60.0 \pm 7.5$ & $1.04 \pm 0.21$ & $0.14 \pm 0.02$ \\
\hline $20.5 \pm 1.9$ & $63.7 \pm 5.9$ & $1.00 \pm 0.35$ & $0.16 \pm 0.02$ \\
\hline $13.6 \pm 1.7$ & $38.1 \pm 5.7$ & $0.76 \pm 0.20$ & $0.21 \pm 0.04$ \\
\hline $12.0 \pm 0$ & $73.0 \pm 0$ & $1.17 \pm 0$ & $0.23 \pm 0$ \\
\hline $11.7 \pm 3.2$ & $43.8 \pm 2.2$ & $0.89 \pm 0.25$ & $0.22 \pm 0.03$ \\
\hline $9.5 \pm 3.0$ & $54.3 \pm 8.7$ & $0.53 \pm 0.22$ & $0.16 \pm 0.03$ \\
\hline $7.8 \pm 3.4$ & $62.3 \pm 13.5$ & $0.75 \pm 0.32$ & $0.18 \pm 0.03$ \\
\hline $10.4 \pm 2.3$ & $75.0 \pm 20.1$ & $0.73 \pm 0.34$ & $0.17 \pm 0.02$ \\
\hline $11.0 \pm 2.2$ & $73.3 \pm 31.3$ & $0.57 \pm 0.29$ & $0.18 \pm 0.04$ \\
\hline $10.8 \pm 3.7$ & $86.3 \pm 27.6$ & $0.59 \pm 0.20$ & $0.16 \pm 0.03$ \\
\hline $11.0 \pm 2.5$ & $67.7 \pm 18.6$ & $1.00 \pm 0.44$ & $0.16 \pm 0.03$ \\
\hline $9.0 \pm 2.0$ & $47.1 \pm 11.5$ & $0.70 \pm 0.24$ & $0.17 \pm 0.02$ \\
\hline $11.8 \pm 4.08$ & $85.1 \pm 22.9$ & $0.97 \pm 0.42$ & $0.17 \pm 0.03$ \\
\hline $8.9 \pm 2.3$ & $66.1 \pm 13.6$ & $0.94 \pm 0.43$ & $0.17 \pm 0.02$ \\
\hline
\end{tabular}

Two RDAs were calculated using the following combination of chronologies: (a) three species (204 trees) and (b) P. uncinata (154 trees). All RDAs were computed for the reference period 1952-1993, which corresponded to the period of meteorological data. Due to the absence of nearby stations with complete long-term records, data from four nearby meteorological stations were combined for the period 1952-1993 (Table 2). These stations are located between $940 \mathrm{~m}$ and $1880 \mathrm{~m}$ a.s.1., elevations lower than our sampling sites, but they represent the best data available for this portion of the Spanish Central Pyrenees. We used the program MET from the Dendrochronology Program Library (Holmes 1992) to estimate the missing data for each station (Table 2) and to combine them. Monthly variables for each station were transformed into normalized standard deviations to give each station the same weight in calculating the mean values for each month and year. For all analyses, mean monthly temperature and total monthly precipitation from May of the year before ring formation $(t-1)$ to October of the year the annual ring formed $(t)$ were used. This period was determined following observations made by Camarero et al. (1998) on the seasonal development of xylem cells in $P$. uncinata and $P$. sylvestris.

Pearson's correlation and bootstrap response functions were calculated using the same climatic data and the PCA scores calculated for the two subsets of chronologies (204 and 154 trees) to compare the RDA results with standard methods in dendroecology. Compared to a correlation function, a response function constitutes a form of multiple regression in which the predictor variables are principal components of the monthly climatic variables. All RDAs and PCAs were calculated from a covariance matrix since our descriptors (tree ring chronologies) were of the same kind, shared the same order of magnitude, and were measured in the same units (Legendre and Legendre 1998).
In these analyses, years were considered as samples (sites) and each tree as a descriptor (species) (Mode Q; see Legendre and Legendre 1998). In RDAs, significant climatic variables $(P<0.05)$ were selected after a forward selection using a Monte Carlo permutation test based on 999 random permutations (Manly 1998). All ordination analyses were computed using the program CANOCO (Version 4.0) and scaling of ordination scores was done using a correlation biplot (ter Braak 1987, 1994). Both Pearson's correlation and bootstrap response functions were calculated with the program PRECON (Version 5.16) (Fritts et al. 1991).

Radial growth-climate association-site factors.We again used RDA to study the relationships between the growth-climate association for each tree and site factors. First, Pearson's correlations that were calculated between the 204 tree residual chronology and the climatic variables (see Methods: Statistical Analyses) were screened and all significant coefficients $(P<0.1)$ were retained and transformed to absolute values. When inverse correlation signs were observed for the same variable (e.g., June precipitation), the variable was duplicated (e.g., June precipitation negative effect and June precipitation positive effect). Only correlations with monthly variables having an occurrence of at least 6 out of the potential 204 were kept in the RDA to limit the influence of rare events. Second, an environmental matrix was constructed using both abiotic and biotic site factors that were assumed to influence the radial growth-climate association of each tree. In this matrix, all classes of the qualitative environmental variables were transformed into dummy binary variables as recommended by ter Braak (1987). The site factors were the following: aspect (4 qualitative variables), elevation $(\mathrm{m})$, slope $\left(^{\circ}\right)$, site (17 qualitative variables), open-closed canopy forest (1 qualitative class), tree height $(\mathrm{m})$, tree diameter at breast height $(\mathrm{cm})$, and tree age (yr). A hierarchical classification analysis was calculated with program TWINSPAN (Hill 1979) using a presence-absence matrix of the dominant tree and understory species to characterize the vegetation type. Seven community types (7 qualitative variables) were defined: Type $1(n=12)$ : $P$. sylvestris, Quercus faginea L., and J. communis; Type $2(n=13)$ : A. alba, Betula spp., F. sylvatica, S. aucuparia, and $S$. aria (L.) Crantz; Type 3 ( $n=19)$ : A. alba, Betula spp., P. uncinata, and mosses; Type $4(n=28): P$. uncinata, $R$. ferrugineum, $V$. myrtillus, J. communis, F. eskia, and Erica tetralix L.; Type $5(n=46)$ : P. uncinata, $R$. ferrugineum, $A$. alba, V. myrtillus, Betula spp., S. minor, S. aucuparia, and $S$. aria; Type $6(n=41): P$. uncinata, $R$. ferrugineum, and V. myrtillus; Type $7(n=45)$ : P. uncinata, and $R$. ferrugineum.

Two RDAs were again calculated using a covariance matrix and the same subset of trees: (a) 204 trees and (b) $154 P$. uncinata. Significant environmental variables $(P<0.05)$ were selected after a forward selection using a Monte Carlo permutation test based on 999 
TABLE 2. Characteristics of the meteorological stations used to compute regional climate for the National Park of Aigüestortes i Estany de Sant Maurici.

\begin{tabular}{|c|c|c|c|c|c|c|c|}
\hline Station & Longitude & Latitude & $\begin{array}{l}\text { Elevation } \\
\text { (m a.s.1.) }\end{array}$ & $\begin{array}{c}\text { Distance } \\
(\mathrm{km}) \dagger\end{array}$ & $\begin{array}{c}\text { Years for } \\
\text { precipitation } \\
\text { data }\end{array}$ & $\begin{array}{l}\text { Mean annual } \\
\text { precipitation } \\
(\mathrm{mm})\end{array}$ & $\begin{array}{c}\text { Missing } \\
\text { values } \\
(\%) \neq\end{array}$ \\
\hline Vielha & $00^{\circ} 48^{\prime} \mathrm{E}$ & $42^{\circ} 42^{\prime} \mathrm{N}$ & 940 & 18 & $\begin{array}{l}1907-1935 \\
1945-1993\end{array}$ & $\begin{array}{l}\ldots \\
987\end{array}$ & $\begin{array}{l}6.0 \\
2.2\end{array}$ \\
\hline Arties & $00^{\circ} 52^{\prime} \mathrm{E}$ & $42^{\circ} 42^{\prime} \mathrm{N}$ & 1185 & 15 & $1952-1991$ & 929 & 10.0 \\
\hline Capdella & $00^{\circ} 59^{\prime} \mathrm{E}$ & $42^{\circ} 28^{\prime} \mathrm{N}$ & 1270 & 13 & 1954-1994 & 1202 & 0.6 \\
\hline Tredós & $00^{\circ} 57^{\prime} \mathrm{E}$ & $42^{\circ} 41^{\prime} \mathrm{N}$ & 1880 & 11 & $1968-1987$ & 862 & 23.3 \\
\hline Pic du Midi & $00^{\circ} 09^{\prime} \mathrm{E}$ & $43^{\circ} 04^{\prime} \mathrm{N}$ & 2862 & 85 & $\begin{array}{l}1882-1922 \\
1923-1936 \\
1937-1984\end{array}$ & $\begin{array}{l}\cdots \\
\cdots \\
990\end{array}$ & $\begin{array}{l}0.0 \\
0.0 \\
9.9\end{array}$ \\
\hline
\end{tabular}

Note: Both mean annual temperature and total precipitation for the reference period 1981-1990 are presented.

$\dagger$ Distance from the meteorological station to the sampling sites.

$\ddagger$ For an explanation of the handling of missing values see Methods: Statistical analyses.

random permutations. In this analysis, trees were regarded as samples (sites) and each monthly correlation coefficient as a descriptor (species) (Mode R; see Legendre and Legendre 1998). We displayed the equilibrium circle of descriptors in the RDA biplot. Those descriptors located outside the circle account for more of the explained variation than those located inside the circle (Legendre and Legendre 1998).

Temporal similarity in radial growth.-To evaluate the temporal stability of the shared variance among tree ring chronologies, we have calculated PCAs for different periods. We chose 50-yr intervals starting in the year 1850 and onward lagged them by $10 \mathrm{yr}$ (i.e., 18501899, 1860-1909, ... 1940-1989, and 1945-1994). The variance explained by the first principal component (PC 1) was used as an indicator of the similarity among the chronologies. As in previous ordination analyses, the data matrix consisted of each tree chronology in a Mode Q analysis (Legendre and Legendre 1998).

For the period 1850-1994 and for each of the 204 tree residual chronologies, years with extreme values $( \pm 1.5 \mathrm{SD})$ were identified and the annual sensitivity was also calculated. The annual sensitivity constitutes the relative difference from one ring-width index to the next and is calculated by dividing the absolute value of the differences between each pair of ring-width indices by the mean of the paired index (Fritts 1976). The frequency of trees showing extremely low $(<1.5$ $\mathrm{SD})$ or high $(>1.5 \mathrm{SD})$ indices and the temporal evolution of annual sensitivity will reveal periods of lower or higher climatic influence through the last $\sim 150$ years. A similar methodology has been employed for extreme climatic values (temperature, precipitation) reconstructed using tree ring widths (Manrique and Fernández-Cancio 2000).

Temporal stability of the radial growth-climate association.-We used the data from the Pic du Midi meteorological station (Table 2) to analyze the temporal stability of the radial growth-climate association. This station has operated since 1882 and data recording was only interrupted during the Second World War and from 1985 to 1993 . The temperature data at Pic du Midi were reported to be homogeneous for the period 1882 1970, but the station was moved to a new building after 1970 (Bücher and Dessens 1991). The monthly mean temperature data from Pic du Midi were found to be highly correlated with those of the four meteorological stations previously used (Arties: mean $r=0.88$, minimum $r=0.75$ and maximum $r=0.96, n=12$; Capdella: mean $r=0.85$, minimum $r=0.73$ and maximum $r=0.93, n=12$; Tredòs: mean $r=0.87$, minimum $r$ $=0.74$ and maximum $r=0.92, n=12$; Vielha: mean $r=0.85$, minimum $r=0.59$ and maximum $r=0.90$, $n=12$ ). The precipitation data from the Pic du Midi station were also found to be homogenous for the periods 1882-1922, 1923-1936, and 1937-1984 (Dessens and Bücher 1997). However, they correlated weakly with those of the Spanish stations and were not used. The low correlation might be explained by the high elevation of this station and the great spatial variability of rainfall in mountainous areas (Barry 1992).

We have calculated new regional mean monthly temperature series to benefit from the potential offered by the Pic du Midi data. We used data from the four meteorological stations displayed in Table 2, and Pic du Midi, which were divided in two homogeneous periods (e.g., both pre-1970 and post-1970 temperature data). We calculated Pearson's correlations using the first two principal components from the eight PCAs previously calculated starting with the period 1880-1929 to assess the stability of the radial growth-climate association. Only $P$. uncinata chronologies were used in this analysis.

\section{Results}

\section{Radial growth-climate association: three species}

The first three axes of the RDA for the period 19521993 expressed $25.06 \%, 4.32 \%$, and $2.56 \%$ of the total variance, respectively. Unless mentioned, only the results from the first two axes are presented. All 204 trees had a positive loading on Axis 1 (Fig. 2A) indicating that all trees were affected in a similar way by the regional climate. In general, chronologies of $P$. uncin- 
TABLE 2. Extended.

\begin{tabular}{ccc}
\hline $\begin{array}{c}\text { Years for } \\
\text { temperature } \\
\text { data }\end{array}$ & $\begin{array}{c}\text { Mean annual } \\
\text { temperature } \\
\left({ }^{\circ} \mathrm{C}\right)\end{array}$ & $\begin{array}{c}\text { Missing } \\
\text { values } \\
(\%)\end{array}$ \\
\hline$\ldots$ & $\ldots$ & $\ldots$ \\
$1951-1993$ & 9.5 & 5.6 \\
$1960-1991$ & 8.4 & 11.2 \\
$1954-1992$ & 8.8 & 0.2 \\
$1968-1987$ & 5.0 & 23.8 \\
$1882-1970$ & $\ldots$ & 0.0 \\
$1971-1984$ & -3.7 & 0.6 \\
$\ldots$ & $\cdots$ & $\cdots$ \\
\hline
\end{tabular}

ata had a higher loading on Axis 1 than that of the other species. November temperature of the year before ring formation $(t-1)$, December precipitation $(t-1)$, and May temperature of the year the annual ring formed $(t)$ were all positively and strongly correlated with Axis 1 (Fig. 2B). Temperatures in September $(t-1)$ and precipitation in September $(t)$ were negatively correlated with Axis 1. Together these variables were responsible for the wider ring-width indices observed in 1953, 1964, 1969, 1982, 1985, and 1990 and the narrower ones observed in 1957, 1963, 1965, 1975, 1984, 1986, and 1991 (data not presented, but narrow and wide ring-width indices can be observed in Fig. 8).

The contrasting radial growth-climate association of the three species was emphasized by the lower scores of A. alba and P. sylvestris on RDA Axis 1. Their position on the second RDA axis provided further information on the growth variations among these species (Fig. 2A). This axis mainly separated P. sylvestris. The main climatic variables correlated to Axis 2 were September $(t-1)$ and June $(t)$ precipitation, both with negative correlation to the axis (Fig. 2B).

As a comparison, the climate influence on radial growth was also investigated using Pearson's correlation and bootstrap response functions calculated between PCA scores and the regional climatic data (Fig. 3). Overall, the results obtained were consistent with those from the RDA (Fig. 3A, B). On PCA Axis 1, tree scores were positively correlated with November $(t-$ 1) and May $(t)$ temperature, and negatively with September $(t-1)$ temperature (Fig. 3A). On Axis 2, May $(t-1)$ precipitation showed a positive association, whereas an inverted one was observed for June $(t)$ precipitation (Fig. 3B). In addition, the bootstrap response function revealed a positive association with July $(t)$ temperature and a negative one with April $(t)$ precipitation.

Radial growth-climate association: P. uncinata only

A second RDA was calculated after eliminating both $A$. alba and $P$. sylvestris to discern the growth pattern of P. uncinata (Fig. 4). The first three axes accounted for $30.08 \%, 2.85 \%$, and $2.12 \%$ of the total variance. Again, the scores on Axis 1 were all positive and

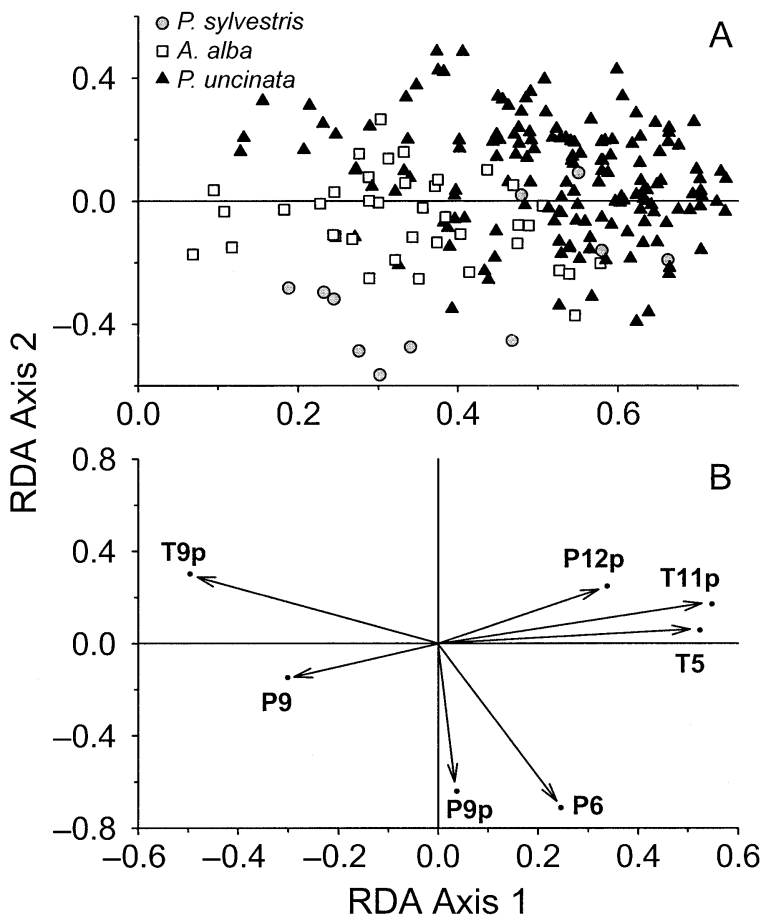

FIG. 2. Redundancy analysis (RDA) calculated from 204 residual chronologies for the period 1952-1993. (A) Species (tree chronology) scores and (B) significant environmental variable (climatic factor) scores. $\mathrm{T}=$ Temperature; $\mathrm{P}=$ Precipitation; month is represented by a number (e.g., $6=$ June); $\mathrm{p}=$ year before ring formation (year $t-1$ ). Note: in RDA biplots, the correlation between biotic and abiotic variables is given by the cosine of the angle between two vectors (arrows). Vectors pointing in roughly the same direction indicate a high positive correlation, vectors crossing at right angles correspond to a near zero correlation, and vectors pointing in opposite directions show a high negative correlation (ter Braak and Prentice 1988). Environmental variables with long vectors are the most important in the analysis. The vectors (arrows) were not drawn in Fig. 2A for visual clarity. The use of the vector's apices is thus only recommended for visual comparison (ter Braak and Verdonschot 1995, Legendre and Legendre 1998).

showed a common pattern for all chronologies (Fig. 4A). The correlations with climatic variables were similar to those of the previous RDA except that September $(t-1)$ temperature was no longer significant (Fig. 4B). The variables that were highly correlated with Axis 1 were December $(t-1)$ precipitation, November $(t-$ 1) temperature, May $(t)$ temperature, and September $(t)$ precipitation. On Axis 2, trees of $P$. uncinata growing at lower elevation (site Sant Maurici) were separated. The main variable positively correlated with this axis was June $(t)$ temperature, whereas June $(t)$ precipitation had the inverse sign (Fig. 4B). Comparison of these results with those from both the correlation and the bootstrap response functions again revealed similar trends (Fig. 3C, D). A positive relationship with both November $(t-1)$ and May $(t)$ temperature was observed with tree scores on PCA Axis 1 (Fig. 3C). On 


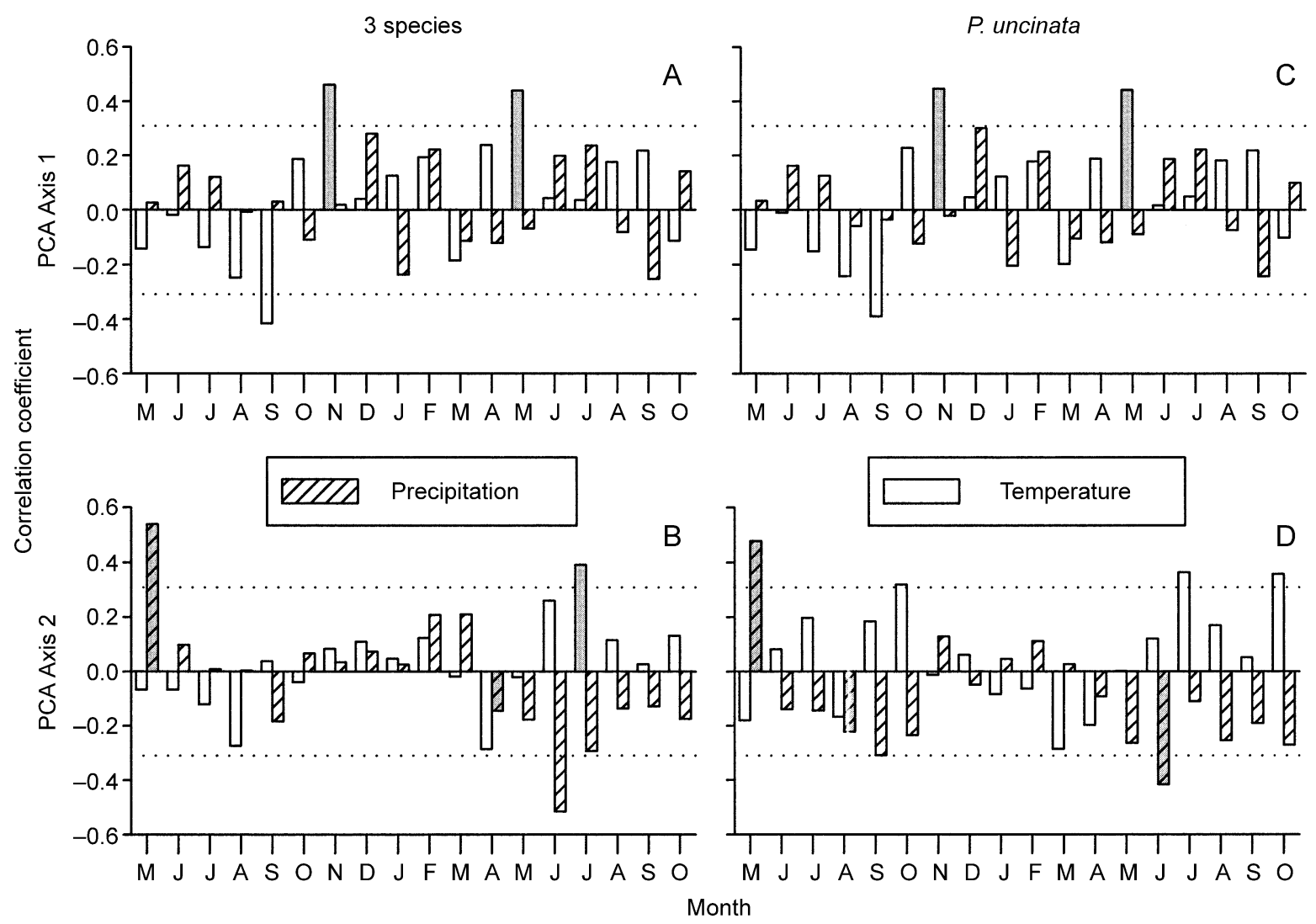

FIG. 3. Correlation and bootstrapped response functions calculated between the sample (year) scores on Axis 1 and Axis 2 derived from PCA and the regional climatic variables. The left graphs (A and B) refer to the calculation using the 204 tree residual chronologies and Axis 1 and Axis 2, respectively. The right graphs (C and D) refer to the PCA using the 154 Pinus uncinata and Axis 1 and Axis 2, respectively. The significance level of the correlations $(P<0.05)$ is indicated by the dotted lines, and significant bootstrapped factors $(P<0.05)$ are indicated by filled bars.

Axis 2, a negative correlation with June precipitation $(t)$ and a positive one of July $(t)$ were observed (Fig. 3D).

\section{Influence of site factors}

The Pearson's correlation calculated between the 204 tree chronologies and the climatic data are summarized in Fig. 5. This figure highlights the dominant influence of temperature on radial growth. The main factors positively associated with radial growth were November $(t-1)$ temperature and May $(t)$ temperature (Fig. 5A). The strongest negative association with tree ring indices were observed with both August and September $(t-1)$ temperature (Fig. 5A). Among the three species, $P$. sylvestris was more frequently and positively associated with warm April ( $t$ ) temperature (Fig. 5A) and abundant June-July $(t)$ precipitation (Fig. 5B). November $(t-1)$ temperature was the only variable positively correlated to $>50 \%$ of the A. alba. More variability among trees was observed for $A$. alba as indicated by numerous climatic variables having a low frequency of significant correlation (Fig. 5). For P. uncinata, the main difference between trees growing at low or high elevation was the higher importance of warmer October $(t-1)$, May $(t)$, and August $(t)$, and dryer May $(t)$ for the latter (Fig. 5).

The first RDA computed using the correlations presented in Fig. 5 (see Methods: Statistical Analyses) showed that the three species occupied different areas in the species-environment biplot and that elevation was the dominant factor correlated with Axis 1 (data not presented). Because of the particular radial growthclimate association presented by $P$. sylvestris and $A$. alba (Fig. 5), a second RDA using only the $154 P$. uncinata was calculated (Fig. 6). Again, the RDA species-environment biplot illustrates how the radial growth-climate association in $P$. uncinata is influenced by elevation. Warm and dry Mays $(t)$ were more strongly associated with high elevation trees (Fig. 6). For trees showing a significant correlation with May $(t)$ temperature, the strength of the coefficient also increased significantly with elevation $(r=0.47, P<$ $0.05, n=93$ ). In contrast, high temperature in August and September $(t-1)$ were more detrimental to low elevation trees. This analysis also shows that a portion of the variance was attributed to site specific conditions 


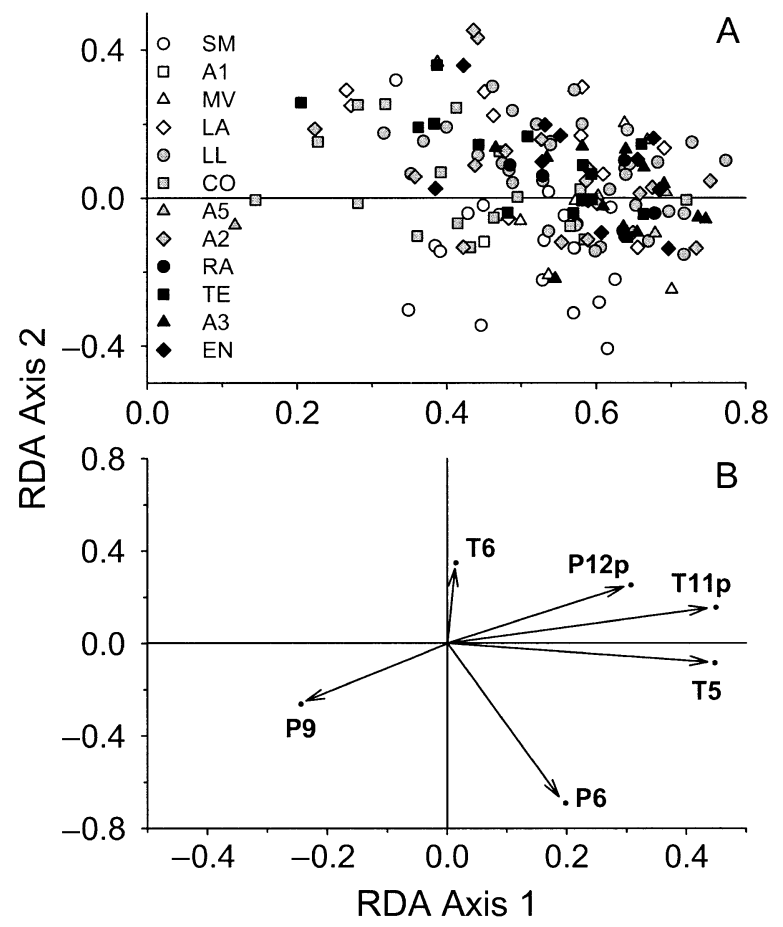

FIG. 4. Redundancy analysis (RDA) calculated from 154 residual chronologies of Pinus uncinata for the period 19521993. (A) Species (tree chronology) scores and (B) significant environmental variable (climatic factor) scores. $\mathrm{T}=\mathrm{Tem}$ perature; $\mathrm{P}=$ Precipitation; month is represented by a number (e.g., $6=$ June), $\mathrm{p}=$ year before ring formation (year $t-$ 1). See caption for Fig. 2.

as indicated by the positions of the site labels in the biplot (Fig. 6B).

\section{Temporal stability of the radial growth-climate association}

The results from the PCAs calculated on 50-yr periods lagged by $10 \mathrm{yr}$ indicated that the percentage of variance extracted by the first principal component was not constant through time (Fig. 7A, B). The variance held in common was high during the period 18501899 , it dropped to a minimum during the period centered around 1890-1939, and then rose to its maximum value during the 1945-1994 period. The low percentage of variance expressed by PC 1 during the period 1900-1950 indicated less shared variation in tree ring indices (i.e., each tree followed a more distinctive growth pattern). This decrease was more pronounced for P. uncinata (Fig. 7B). The sum of squares for each PCA also showed the same trend as PC 1 ss on Fig. 7). It reached a maximum in the last $50 \mathrm{yr}$ indicating that ring-width indices are deviating more from the mean.

Since the 1950s, both narrow and wide tree rings were more frequently registered by the three tree species (Fig. 8A-D) and especially by high elevation $P$. uncinata (Fig. 8D). In comparison, the period from $\sim 1900$ to 1950 showed less extreme tree rings indices in all chronologies. Both A. alba and high elevation $P$. uncinata showed a sharp decrease in the frequency of narrow and wide tree rings during this period (Fig. 8B, D). This phenomenon was confirmed by annual sensitivity values, which showed a sustained rise starting in the 1950s for all species (Fig. 9). Year-to-year change in radial growth indices in $P$. uncinata has increased since the $1950 \mathrm{~s}$ and reached the maximum for the last 150 years (Fig. 9C, D).

In relation to the pattern encountered in the second half of the 20th century (higher shared variance, higher occurrence of extreme years, and higher sensitivity), our results indicated that the radial growth-climate association of $P$. uncinata varied across time (Fig. 10). From the period 1880-1929 to 1910-1959, few climate variables were correlated with PCA Axis 1 (Fig. 10). These periods coincided with low shared variation among trees (Figs. 7-9). A negative correlation with warm August-September $(t-1)$ started in the 1920s, whereas the positive effect of warm October-November $(t-1)$ started in the 1930s. The positive correlation with May $(t)$ temperature was initiated in the 1940s. The correlations between the tree scores on Axis 1 and the environmental variables revealed that elevation was

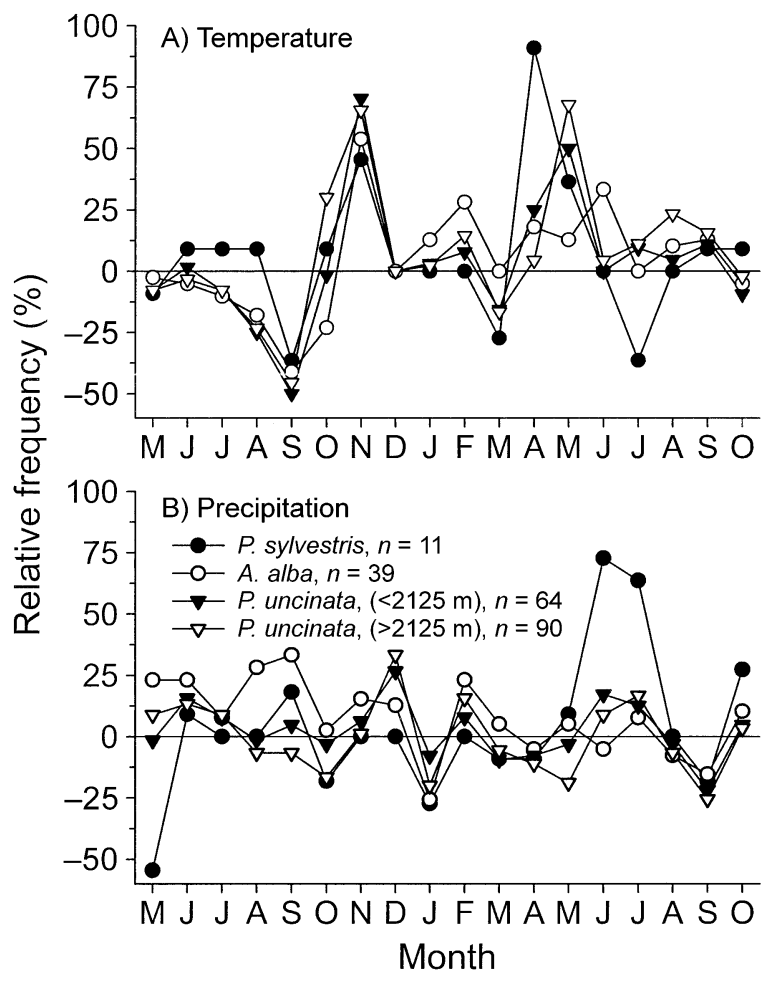

FIG. 5. Relative frequency of trees presenting significant $(P<0.1)$ Pearson's correlation coefficients with mean monthly climatic variables: (A) temperature; (B) precipitation. Relative frequencies of both positive and negative correlation coefficients are indicated. 


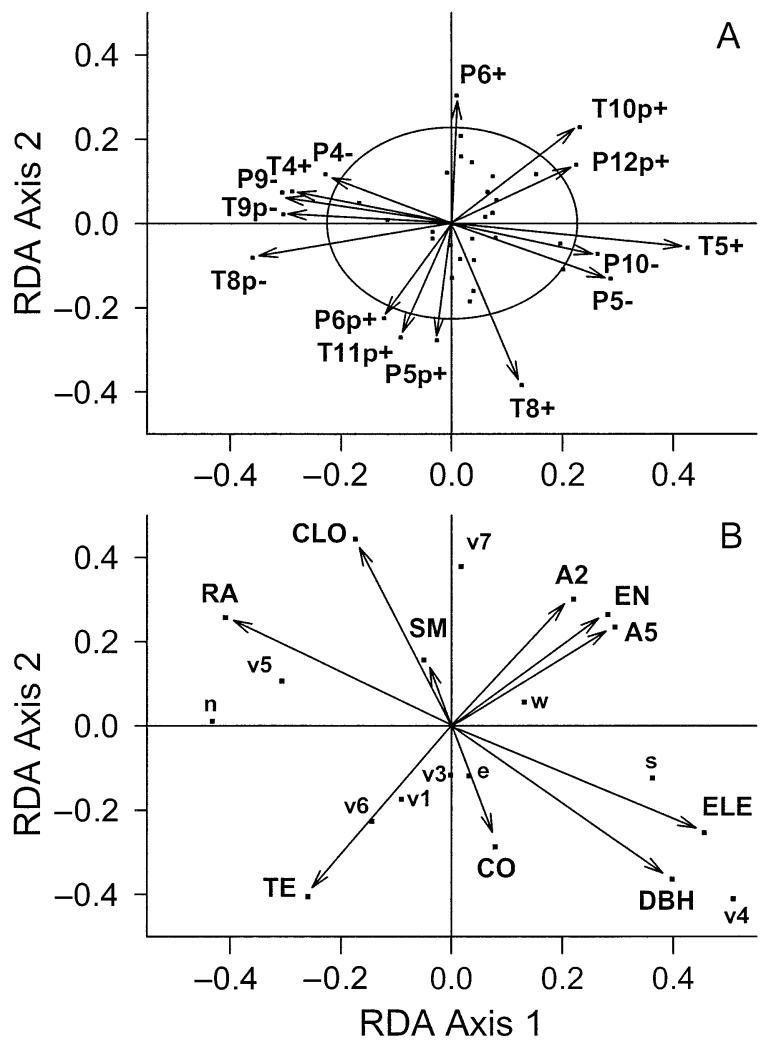

FIG. 6. Redundancy analysis (RDA) calculated using the Pearson's correlation coefficients matrix (154 Pinus uncinata) and the environmental data. (A) Species scores (significant correlation with climatic variables). The equilibrium circle of the descriptors is displayed. $\mathrm{T}=$ Temperature; $\mathrm{P}=$ Precipitation; month is represented by a number (e.g., $6=$ June); $\mathrm{p}=$ year before ring formation (year $t-1$ ); and + or indicate the sign of the correlation coefficient. (B) Environmental factor scores. The significant factors after 999 Monte Carlo iterations were the RA, SM, A2, A5, EN, TE, and CO sites (see Table 1) and the following variables: ELE = elevation, $\mathrm{CLO}=$ closed canopy, and $\mathrm{DBH}=$ tree diameter at breast height. The scores of vegetation clusters (v1, v3, v5, v6, and v7) and aspect (north, east, south, and west) were not significant and were made passive in the RDA. The vectors are thus not shown for these variables. Interpretation of this figure follows Fig. 2. For example, the vectors for species $\mathrm{T} 8+$ and environmental factor $\mathrm{CO}$ are pointing in the same direction and the cosine of the angle between the two vectors indicates a positive correlation between the variables. In other words, trees growing at site $\mathrm{CO}$ present a higher correlation coefficient with August temperature (positive effect).

not significantly related to tree scores during the 19101959 to $1930-1979$ periods (data not presented).

In contrast, tree scores on Axis 2 were clearly related to elevation. For all periods, elevation was significantly correlated with tree scores at a $P$ value of 0.0001 . The correlation with elevation also slightly increased with time (1850: $r=0.46,1860: r=0.45,1870: r=0.48$, 1880: $r=0.60,1890: r=0.61,1900: 0.57,1910: r$ $=0.60,1920: r=0.57,1930: r=0.55,1940: r=$ -0.50 and 1945: $r=-0.51)$. The correlation with Axis 2 indicated that February $(t)$ temperature in the periods
1880-1929 to 1900-1949 was positively correlated with growth differences between low and high elevation trees (Fig. 10). The negative correlation with October $(t-1)$ was observed in all periods but showed a decrease in the later decades. This decrease, however, coincided with increasing correlations with Axis 1 (Fig. $10)$. Since the beginning of the 20th century, the correlation of July $(t)$ temperature with tree scores on Axis 2 has increased.

\section{Discussion}

\section{Radial growth-climate association}

Our analyses showed that radial growth of Abies alba, Pinus sylvestris (one site sampled), and Pinus uncinata from the Central Pyrenees was influenced by the regional climate. For the period 1952-1993, all species growth was negatively associated with warm September $(t-1)$ and positively associated with both warm November $(t-1)$ and May $(t)$ temperatures. For both $P$. uncinata (Gutiérrez 1991, Rolland et al. 1995, Petitcolas and Rolland 1998, Rolland and Schueller 1998) and A. alba (Rolland 1993, Rolland et al. 1999), it has been reported that the weather conditions during the growing season before ring formation $(t-1)$ had a stronger influence on radial growth than during the year the annual ring formed $(t)$. Pinus sylvestris was the exception to this pattern (Richter 1988).

Radial growth in $P$. sylvestris was positively correlated with April $(t)$ temperature, which could indicate a benefit of having an earlier onset of growing season (Richter 1988, Richter and Eckstein 1990). Compared to the other species, $P$. sylvestris may also be more susceptible to deficits in the water balance during the year the annual ring formed $(t)$. This was suggested by the positive relationship with June-July precipitation and the negative one with July temperature. In our study, the lowest sites were occupied by A. alba. Radial growth in this species was better when cool and humid conditions characterized the summer before ring formation (Rolland 1993, Rolland et al. 1999). Abies alba growth was also negatively associated with warm October temperature in the year before ring formation. The importance for this species of the water balance in the prior growing season has been observed in both short-term ecophysiological (Guelh and Aussenac 1987) and long-term dendroclimatological studies (Rolland 1993).

In $P$. uncinata, temperature was the main factor related to radial growth. Warm Novembers in the year before ring formation and warm Mays during the year of ring formation dominated the growth-climate association. Rolland and Schueller (1994) attributed the positive impact of May temperature to maximum temperature. Our data showed, however, that both minimum and maximum May temperatures from Pic du Midi were correlated with radial growth of $P$. uncinata (data not presented). An earlier growth resumption 

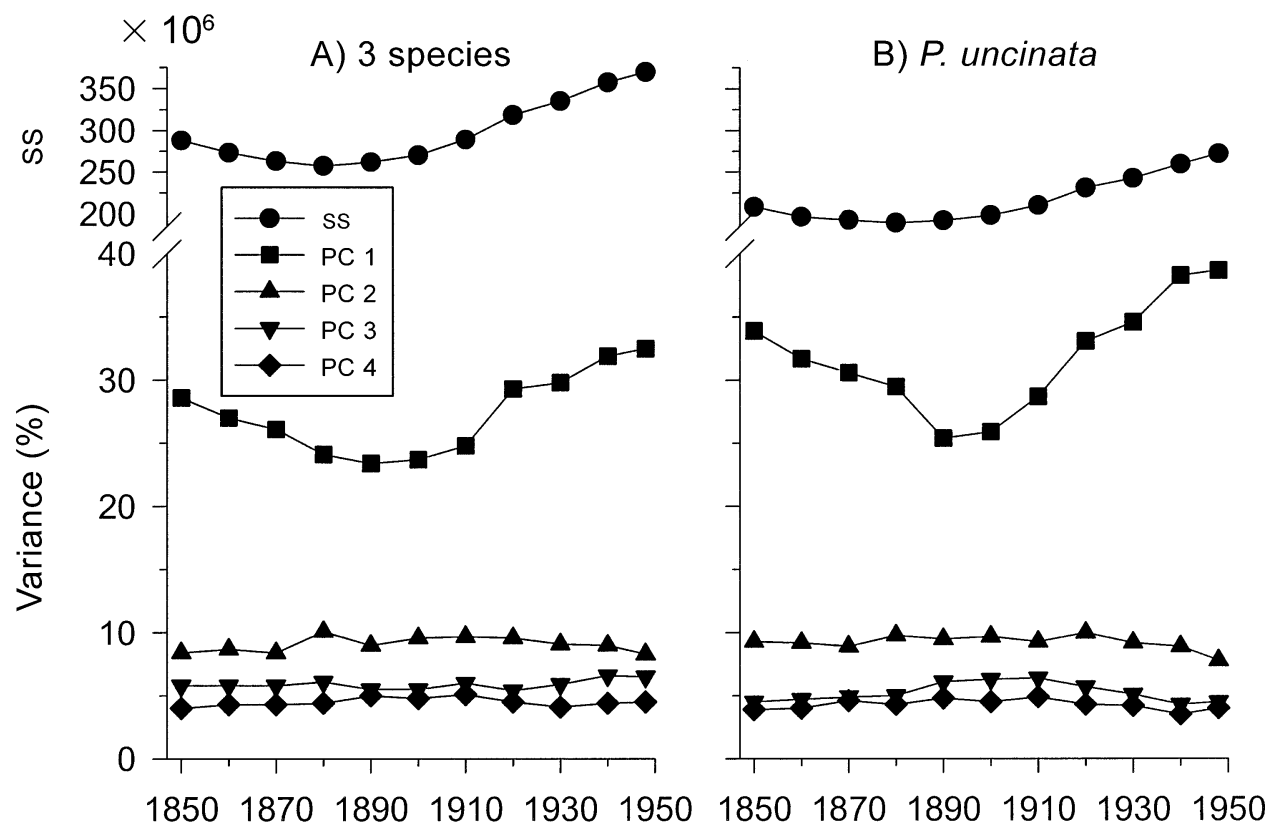

FIG. 7. Principal component analysis (PCA) calculated for periods of $50 \mathrm{yr}$ starting in year 1850 and onward, lagged by 10 yr. (A) Three species (204 trees) and (B) Pinus uncinata. ss = total sum of the squares of the species data.

could be associated with warmer Mays. In the Central Pyrenees, both $P$. uncinata and $P$. sylvestris may begin radial growth near the end of May (Camarero et al. 1998).

In the Pyrenees, the dominant effect of temperature over precipitation has also been reported in many studies (Creus and Puigdefábregas 1976, Génova 1986, Ruiz-Flaño 1988, Rolland and Schueller 1994, 1998). This contrasts with results from the French Alps, where August-September precipitation in the year before ring formation was positively related to radial growth (Rolland and Schueller 1996). Our results suggested that thermal stress in late summer and cold temperature during fall could limit the formation of metabolic reserve and consequently affect radial growth in the following year (Rolland and Schueller 1994).

\section{Influence of site factors}

In mountain environments, climatic parameters strongly depend on elevation (Barry 1992), whereas other factors like slope, aspect, or protection from intense wind can also influence tree growth at a local scale. In this study, elevation was the main factor related to variation in the growth-climate association of $P$. uncinata. Radial growth of higher elevation $P$. uncinata was favored by warmer temperatures at the end of the previous growing season and at the beginning of the growing season compared to lower elevation $P$. uncinata. The positive influence of late spring-early summer temperature on trees growing near the upper treelike was also observed by Villalba et al. (1997). This is consistent with the fact that the cambial reac- tivation of evergreen conifers is triggered by a rise in temperature (Tranquillini 1979, Oribe and Kubo 1997).

It is also well established that the ability of trees to grow in high elevation sites is related to the length of the growing season (Tranquillini 1979). Hansen-Bristow (1986) demonstrated that both air and soil temperatures were important factors triggering bud flush in conifer species growing at the timberline. It has also been suggested that soil temperature could be the main factor controlling the altitudinal limit of the arborescent growth form (Körner 1998). A prolongation of the growing season caused by climatic warming would thus be more beneficial to high elevation $P$. uncinata stands. Our results also showed that low elevation trees $(P$. sylvestris, A. alba, low elevation $P$. uncinata) were more susceptible to hydric stress. Lower elevation trees showed strong negative correlations with both August and September temperature of the year before ring formation. Similar conclusions were also reached along an altitudinal gradient in the French Alps (Schueller and Rolland 1995, Rolland and Schueller 1996).

\section{Temporal variability of radial growth}

Our results indicate that the shared variance held by the tree chronologies was not stable through time. The same was observed with the growth-climate association of $P$. uncinata. Of particular interest was the period 1900-1949, which showed few years with either extremely low or high ring-width indices. In contrast, indices with extreme values were most frequent during the period 1950-1994. This also coincided with an increase in the annual sensitivity. Comparison with other 

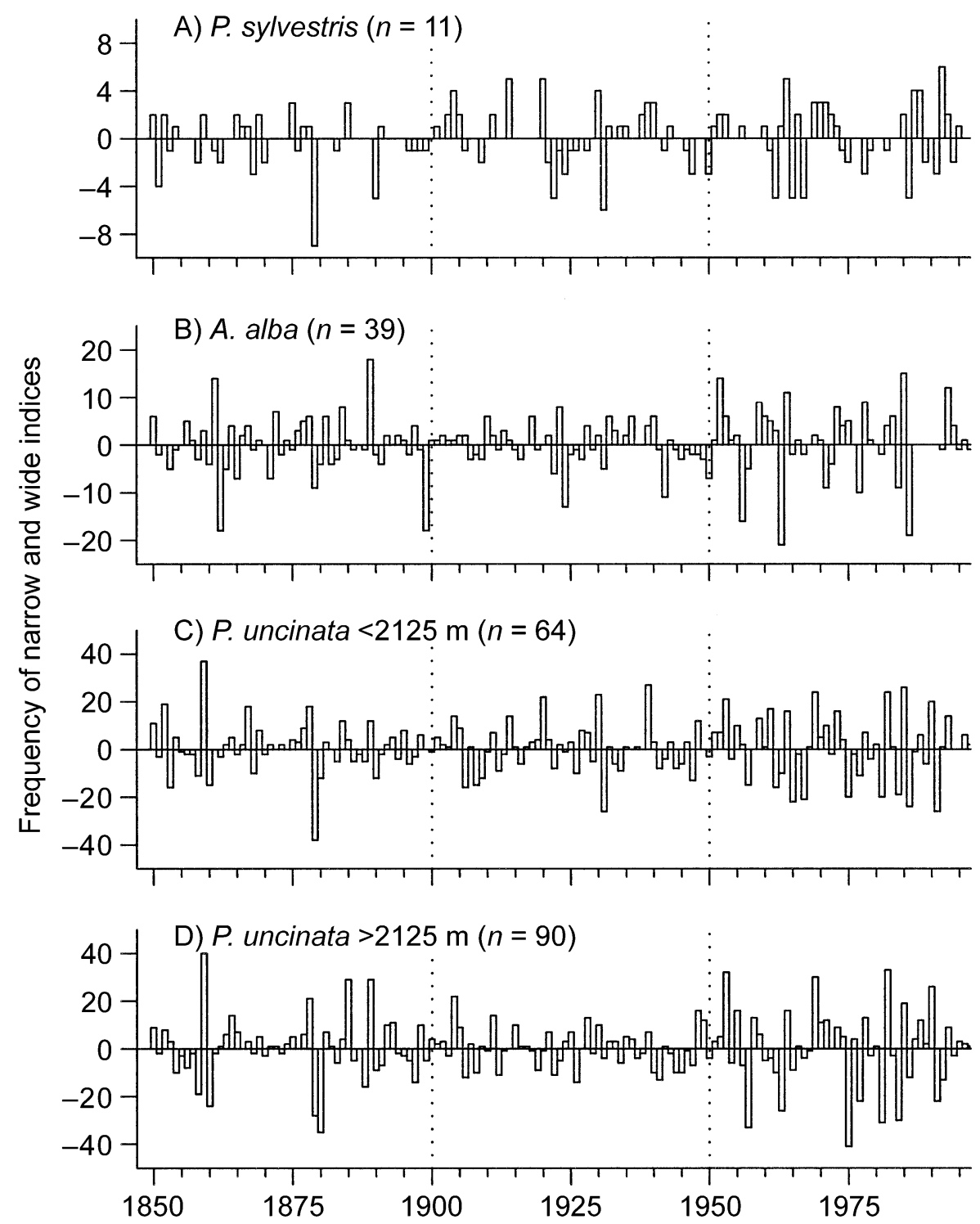

FIG. 8. Temporal distribution of narrow $(<1.5 \mathrm{SD})$ and wide $(>1.5 \mathrm{SD})$ ring-width indices for each species during the period 1850-1994: (A) Pinus sylvestris, (B) Abies alba, (C) low-elevation Pinus uncinata, and (D) high-elevation P. uncinata.

chronologies in the region indicated that they also presented fewer extreme values during the period from $\sim 1890$ to 1950 (for P. uncinata, see Génova 1987; for P. sylvestris, see Richter 1988).

In a study of the temporal stability of the growthclimate association in P. sylvestris, Tessier (1989) observed great temporal differences among populations, and attributed these changes to site disturbances and successional changes. It was generalized that spatial and temporal variability in the growth-climate association over a given period within the same climatic region merely reflect similarities or differences in the structure of the forest stands (Tessier 1989, Tessier et al. 1997). We suggest that this phenomenon is also a consequence of climatic variability imposed over suc- cessional changes. Since temperature and precipitation vary with elevation, climate change may modify the growth-climate association (i.e., if climatic conditions are becoming either more or less favorable to growth). The described growth-temperature relationships may thus be indicative of recent growth changes of subalpine conifers in the Central Pyrenees (Gutiérrez et al. 1998).

Our results emphasized the presence of temporal variation in the radial growth-climate association. Neither the shared variation among tree radial growth indices, the frequency of characteristics rings, nor tree sensitivity has been constant through time. This may be critical and should be considered for more realistic reconstruction of past climatic conditions using tree 

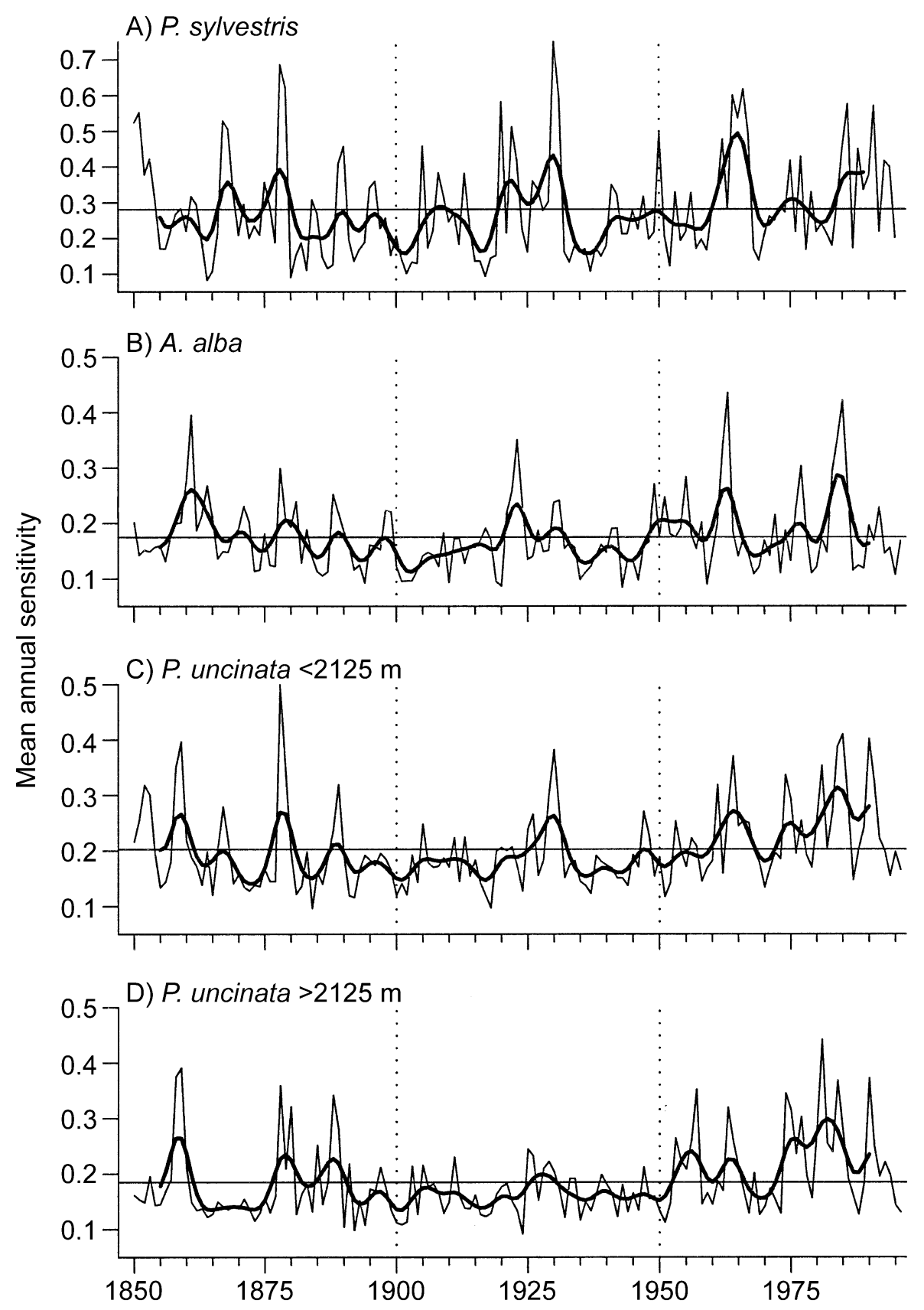

FIG. 9. Temporal changes in mean annual sensitivity for each species during the period 1850-1994 (see Methods: Temporal similarity in radial growth). The thin line represents yearly change in sensitivity, and the bold line represents a low-pass filter as described by Fritts (1976). The horizontal lines represent the average mean annual sensitivity. (A) Pinus sylvestris, (B) Abies alba, (C) low-elevation Pinus uncinata, and (D) high-elevation P. uncinata.

rings. The temporal analysis of the shared variance among tree chronologies along an ecological gradient has allowed us to identify periods where climate was likely most influential. In absence of long-term climatic data, coupling of these analyses with standard dendroclimatic reconstruction may help to strengthen our understanding of the influence that changing climate has on tree growth by providing complementary information that otherwise may not be picked up.

Our results showed that the period corresponding to the end of the Little Ice Age and the last 50 years were both characterized by greater affinity among chronologies. We speculate that three distinct periods characterized by important changes in the regional climate 


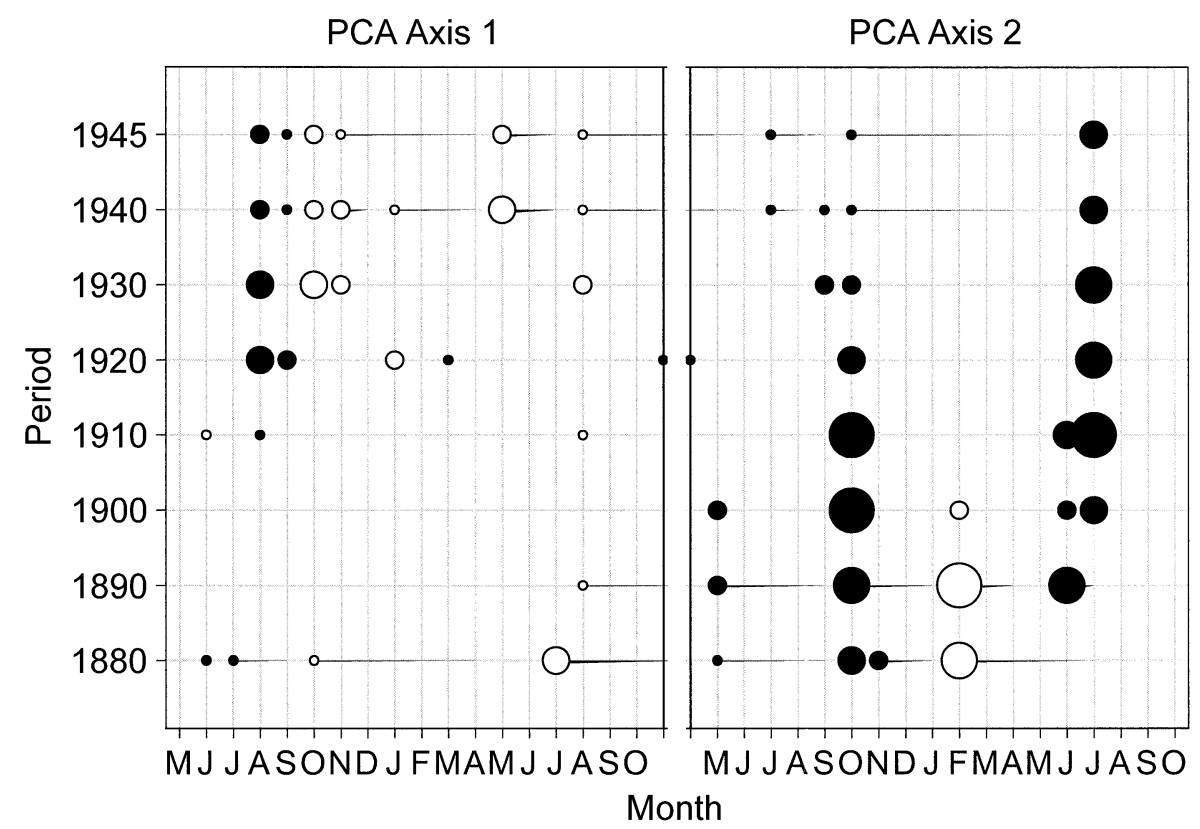

FIG. 10. Temporal changes in the correlation between the yearly scores on the first two principal components and the monthly temperature for eight $50-\mathrm{yr}$ periods starting in 1880 . The strength of the correlation is indicated by the size of the circle (from the smallest to the largest: $P<0.1, P<0.05, P<0.01$, and $P<0.001$ ). Open circles indicate a positive correlation, and solid circles indicate a negative correlation.

have occurred since the 1850 s. First, a climate system characterized by a shorter growing season than today dominated the late 19th century. This is suggested by the strong shared variance among trees from all sites. Our results suggest that the turn of the 20th century constituted a transitional climate phase between the end of the Little Ice Age period and the current period. Font Tullot (1988) described the period 1881-1895 as very cold in Spain, marking the start of a warming trend in the beginning of the 20th century (see also Fontana Tarrats 1975-1978, 1976).

Since the beginning of the 20th century, increasing dissimilarity was observed among chronologies, indicating that climate was less limiting to growth. This coincided with a generalized decrease in the frequency of extremely low or high indices for the period 19001950. Few climate variables were also correlated to growth during this period. Results showed that site elevation was not a major factor influencing growth of $P$. uncinata during that period. Warmer, more humid conditions with low year-to-year variability may have brought a "disruption" or "relaxation" of the elevation gradient, allowing local growth conditions to dominate.

From the mid 20th century, climate conditions have again become more limiting to growth, as suggested by increasing similarity among the tree chronologies. Year-to-year variation in climatic conditions has also increased as illustrated by the higher sensitivity and extreme growth indices recorded by the trees. Font Tullot (1988) reported an increase in the frequency of extreme climatic events (high temperatures, frosts, droughts) in the last 50 years. Other authors have found an increase in climatic anomalies in Spain since $\sim 1940$ (Manrique and Fernández-Cancio 2000). This is consistent with our dendroecological results.

Climate conditions acting at both lower and higher elevation may be at the origin of this trend. Overall, it appears that temperatures in late summer and fall during the year before ring formation and spring (May) temperatures during the year of ring formation have become more limiting to growth today. This may reflect changes in the timing or length of the growing season (Hansen-Bristow 1986). In the Central Pyrenees and during the second half of the 20th century, the growth season of $P$. uncinata may have increased as well as the water stress during the growth period. This "steepening" of the gradient could also cause the elevation of the tree line and other changes (Camarero 1999).

The interpretation of the evolution of the climatic response determined and calculated using the Pic du Midi data must, however, be viewed critically. Throughout the 1882-1993 period, the spatial coverage of the meteorological stations was irregular. In addition, no detailed analyses of extreme climatic events were realized. In the long term, factors that may have changed are both the continentality (change in air mass penetration in the region) and the effect of elevation in relation to the ecological amplitude of $P$. uncinata. The absence of long-term precipitation data for the region makes it difficult to discuss climate change in terms of air mass penetration. However, the rainfall pattern in the Iberian Peninsula is influenced by both 
the North Atlantic Oscillation (NAO) and the El Niño Southern Oscillation (ENSO) (Rodó et al. 1997, Rodríguez-Puebla et al. 2001). Though most of the Iberian Peninsula is under NAO influence during winter, the correlation between ENSO and rainfall increased toward the end of the 20th century (Rodó et al. 1997). The percentage of springtime variability due to ENSO has similarly increased. In the 1980s and 1990s, the Iberian Peninsula was also under the influence of extended periods of drought and mild winter. These drier conditions in southwestern Europe were associated with a persistent positive phase of the NAO during winter (Hurrell 1995). Longer growing seasons were also reported to occur during positive phases of the NAO in Europe (Post and Stenseth 1999).

Whether the climatic interpretation of our results is indicative of a general climatic instability is still a matter for debate. Temperature data from the Pic du Midi station are probably representative of the Central Pyrenees region as suggested by the strong correlation among all stations for the common period. These data show a drastic increase of minimum temperatures, a decrease of diurnal temperature ranges, and an increase of temperature variability since $\sim 1940$ (Bücher and Desssens 1991, Dessens and Bücher 1995, 1997).

\section{Conclusion}

The results presented here demonstrated that radial growth of $P$. sylvestris, A. alba, and $P$. uncinata was affected in similar ways by macroclimatic conditions. Although all species responded negatively to warm September $(t-1)$ and positively to both warm November $(t-1)$ and May $(t)$ temperatures, each species also showed a specific radial growth-climate association. Pinus sylvestris may be more susceptible to hydric stress during the year the annual ring forms, whereas A. alba appears to be more sensitive to hydric stress during the year before ring formation. Pinus uncinata radial growth was, in contrast, primarily associated with monthly temperature variables. Moreover, local ecological factors like elevation modulated the strength of the response of trees to climate. This study showed the usefulness of multivariate analyses like RDA for decomposing the tree-climate-site complex. Our results indicated the presence of temporal variation in the radial growth-climate association. Neither the shared variation among tree radial growth indices, the frequency of characteristics rings, nor tree sensitivity have been constant through time. Of particular importance was the early 20 th century period that was characterized by low shared variation in contrast to the late 20th century period. We speculate that climate change may underlie this trend and that trees have adjusted to new climatic conditions. In absence of long-term climatic data, analysis of the temporal evolution of the shared variance among chronologies (estimators) as well as of other tree ring characteristics may be critical and should be considered for more realistic reconstruction of past climatic conditions.

\section{ACKNOWLEDGMENTS}

We thank the personnel of the Park for their help during sampling. We are also grateful to J. A. Romero, M. A. Rodríguez, X. Lluch, O. Bosch, P. Sheppard, E. Schwartz, and F. Conciatori, and many other people for their help during field sampling or laboratory tasks, and to Dr. Dessens for providing the Pic du Midi meteorological data. We thank Dr. S. Forbes and Dr. R. Staniforth for reviewing the manuscript for its prose. The constructive and critical comments made by Dr. F. Biondi, Dr. S. Jackson (Associate editor), and one anonymous reviewer greatly improved the clarity and scope of the manuscript. This research was financed by the Spanish CICyT (AMB95-0160) and through the EU FORMAT project (ENV4-CT97-0641). During this study, J. Tardif benefited from a postdoctoral fellowship from the Fonds FCAR and the programme de coopération Québec-Catalogne, and J. J. Camarero benefited from a FPI grant (Ministerio de Educación y Ciencia, Spain). We thank all institutions for their support.

\section{Literature Cited}

Allué, J. L. 1990. Atlas fitoclimático de España. Ministerio de Agricultura Pesca y Alimentation, Instituto Nacional de Investigationes Agrarias, Madrid, Spain.

Aniol, R. W. 1983. Tree-ring analysis using CATRAS. Dendrochronologia 1:45-53.

Barry, R. G. 1992. Mountain climatology and past and potential future climatic changes in mountain regions: a review. Mountain Research and Development 12:71-86.

Beeckman, H. 1992. Redundancy analysis of tree rings and meteorological data in a Nelder design poplar plantation. Pages 22-26 in T. S. Bartholin, B. E. Berglund, D. Eckstein, and F. H. Schweingruber, editors. Tree rings and environment, Lundqua Report, Volume 34, Sweden.

Beniston, M., H. F. Diaz, and R. S. Bradley. 1997. Climatic change at high elevation sites: an overview. Climatic Change 36:233-251.

Blasing, T. J., D. N. Duvick, and E. R. Cook. 1983. Filtering the effects of competition from ring-width series. Tree-Ring Bulletin 43:19-30.

Bücher, A., and J. Dessens. 1991. Secular trend of surface temperature at an elevated observatory in the Pyrenees. Journal of Climate 4:859-868.

Camarero, J. J. 1999. Growth and regeneration patterns and processes in Pinus uncinata Ram.: treeline ecotones in the Pyrenees and in an isolated population in the Western distribution limit in Spain. Dissertation. University of Barcelona, Barcelona, Spain.

Camarero, J. J., J. Guerrero-Campo, and E. Gutiérrez. 1998. Tree-ring growth and structure of Pinus uncinata and Pinus sylvestris in the Central Spanish Pyrenees. Arctic and Alpine Research 30:1-10.

Cantegrel, R. 1983. Le Pin à crochets pyrénéen: biologie, biochimie, sylviculture. Acta Biologica Montana 2-3:87330.

Carreras, J., E. Carrillo, R. M. Masalles, J. M. Ninot, I. Soriano, and J. Vigo. 1996. Delimitation of the supra-forest zone in the Catalan Pyrenees. Bulletin de la Societé Linnéenne de Provence 47:27-36.

Carrillo, A., and J. M. Ninot. 1992. Flora i vegetació de les valls d'Espot i de Boí. Institut d'Estudis Catalans. Archivo Sección Ciencies XCIX/2:1-351.

Ceballos y Fernández de Córdoba, L., and J. Ruiz de la Torre. 1979. Árboles y arbustos de la España Peninsular. Escuela Técnica Superior de Ingenieros de Montes, Madrid, Spain. Cook, E. R. 1985. A time series analysis approach to treering standardization. Dissertation. Department of Geosciences, University of Arizona, Tucson, Arizona, USA. 
Cook, E. R., and L. A. Kairiukstis, editors. 1990. Methods of dendrochronology. Kluwer, Boston, Massachusetts, USA.

Cook, E. R., and K. Peters. 1981. The smoothing spline: a new approach to standardizing forest interior tree-ring width series for dendroclimatic studies. Tree-Ring Bulletin 41:45-53.

Creus, J. 1991-1992. Tendencia secular de la temperatura de Mayo en el Pirineo Oriental. Notes de Geografia Física 2122:41-49.

Creus, J., M. Génova, A. F. Cancio, and A. P. Antelo. 1992. New dendrochronologies for Spanish Mediterranean Zone. Pages 76-78 in T. S. Bartholin, B. E. Berglund, D. Eckstein, and F. H. Schweingruber, editors. Tree rings and environment, Lundqua Report, Volume 34, Sweden.

Creus, J., and J. Puigdefábregas. 1976. Climatología histórica y dendrocronología del Pinus uncinata Ramond. Cuadernos de Investigación, Logroño (Spain) 2:17-30.

Del Barrio, G., J. Creus, and J. Puigdefábregas. 1990. Thermal seasonality of the high mountain belts of the Pyrenees. Mountain Research and Development 10:227-233.

Dessens, J., and A. Bücher. 1995. Changes in minimum and maximum temperatures at Pic du Midi in relation with humidity and cloudiness, 1882-1984. Atmospheric Research 37:147-162.

Dessens, J., and A. Bücher. 1997. A critical examination of precipitation records at the Pic du Midi observatory, Pyrenees, France. Climatic Change 36:345-353.

Diaz, H. F., and R. S. Bradley. 1997. Temperature variations during the last century at high elevation. Climatic Change 36:254-279.

Folland, C. K., T. R. Karl, and K. Y. Vinnikov. 1990. Observed climate variations and change. Pages 195-238 in J. T. Houghton, G. J. Jenkins, and J. J. Ephraums, editors. Climate changes, the IPCC scientific assessment. Cambridge University Press, Cambridge, UK.

Font Tullot, I. 1988. Historia del clima de España. Cambios climáticos y sus causas. Instituto National de Meteorologia, Madrid, Spain.

Fontana Tarrats, J. M. 1975-1978. "Entre el cardo y la rosa." Historia del clima de la Meseta. (Inéditas).

Fontana Tarrats, J. M. 1976. Historia del clima en Cataluña. Noticias antiguas y medievales, y en especial de los siglos XV, XVI y XVII. (Inéditas).

Fritts, H. C. 1976. Tree rings and climate. Academic Press, New York, New York, USA.

Fritts, H. C., E. A. Vaganov, I. V. Sviderskaya, and A. V. Shashkin. 1991. Climatic variation and tree-ring structure in conifers: empirical and mechanistic models of tree-ring width, number of cells, cell-size, cell-wall thickness and wood density. Climate Research 1:97-116.

Génova, R. 1986. Dendroclimatology of mountain pine ( $\mathrm{Pi}$ nus uncinata Ram.) in the Central plain of Spain. Tree-Ring Bulletin 46:3-12.

Génova, R. 1987. Análisis y significado de los anillos de crecimiento de dos especies forestales: Pinus uncinata y Pinus sylvestris, en la Península Ibérica. Dissertation. University of Barcelona, Barcelona, Spain.

Gil Pelegrín, E., and L. Villar Pérez. 1988. Structure of mountain pine (Pinus uncinata) populations at its upper limit in Central Pyrenees. Pirineos 131:25-42.

Gómez Manzaneque, F., editor. 1997. Los bosques ibéricos: una interpretación geobotánica. Planeta, Barcelona, Spain.

Grace, J., and D. A. Norton. 1990. Climate and growth of Pinus sylvestris at its upper altitudinal limit in Scotland: evidence from tree growth-rings. Journal of Ecology 78: 601-610.

Guelh, J. H., and G. Aussenac. 1987. Photosynthesis decreases and stomatal conductance in Abies alba Mill. in response to vapour pressure difference. Plant Physiology 83:316-322.

Guisan, A., L. Tessier, J. I. Holten, W. Haeberli, and M. Baumgartner. 1995. Understanding the impact of climate change on mountain ecosystems: an overview. Pages 15-37 in A. Guisan, J. I. Holten, R. Spichiger, and L. Tessier, editors. Potential ecological impacts of climatic change in the Alps and Fennoscandian mountains. Conservacíon Jardin Botaníco, Genève, Switzerland.

Gutiérrez, E. 1991. Climate tree-growth relationships of Pinus uncinata Ram. in the Spanish pre-Pyrenees. Acta Oecologica 12:213-225.

Gutiérrez, E., J. J. Camarero, J. Tardif, O. Bosch, M. Ribas, E. Schwartz, P. R. Sheppard, and F. Conciatori. 1998. Xarxa de dendrocronologies establertes al P.N. d'Aiguestortes i Estany de Sant Maurici: avaluació per a estudis dendroecològics i climàtics a llarg termini. Pages 39-74 in IV Jornades sobre Recerca al Parc Nacional d'Aiguestortes i Estany de Sant Maurici. Espot 22-24 October 1997.

Hansen-Bristow, K. 1986. Influence of increasing elevation on growth characteristics at timberline. Canadian Journal of Botany 64:2517-2523.

Hill, M. O. 1979. TWINSPAN, a Fortran program for arranging multivariate data in a ordered two-way table by classification of the individuals and attributes. Department of Ecology and Systematics, Cornell University, Ithaca, New York, USA.

Holmes, R. L. 1983. Computer-assisted quality control in tree-ring dating and measurement. Tree-Ring Bulletin 43: $68-78$.

Holmes, R. L. 1992. Dendrochronology program library. Version 1992-1. Laboratory of Tree-Ring Research, University of Arizona, Tucson, Arizona, USA.

Houghton, J. T., L. G. Meira Filho, B. A. Callander, N. Harris, A. Kattenberg, and K. Maskell, editors. 1996. Climate change 1995: the science of climate change. Cambridge University Press, Cambridge, UK.

Hughes, M. K., B. Gray, J. R. Pilcher, and V. C. Lamarche, Jr. 1978. Climatic signal in British Isles tree ring chronologies. Nature 272:605-606.

Hurrell, J. W. 1995. Decadal trends in the North Atlantic Oscillation: regional temperatures and precipitation. Science 269:676-679.

Jones, P. D. 1994. Hemispheric surface air temperature variations: a reanalysis and an update to 1993 . Journal of Climate 7:1794-1802.

Kienast, F., F. H. Schweingruber, O. U. Braker, and E. Schar. 1987. Tree-ring studies on conifers along ecological gradients and potential of single-year analyses. Canadian Journal of Forest Research 17:683-696.

Körner, C. 1998. A re-assessment of high elevation treeline positions and their explanation. Oecologia 115:445-459.

Legendre, P., and L. Legendre. 1998. Numerical ecology. Elsevier, New York, New York, USA.

Luckman, B. H. 1990. Mountain areas and global change: a view from the Canadian Rockies. Mountain Research and Development 10:183-195.

Manly, B. F. J. 1998. Randomization, bootstrap and Monte Carlo methods in biology. Second edition. Chapman and Hall, London, UK.

Manrique, E., and A. Fernández-Cancio. 2000. Extreme climatic events in dendroclimatic reconstructions from Spain. Climatic Change 44:123-138.

Oribe, Y., and T. Kubo. 1997. Effect of heat on cambial reactivation during winter dormancy in evergreen and deciduous conifers. Tree Physiology 17:81-87.

Petitcolas, V., and C. Rolland. 1998. Comparaison dendroécologique de Larix decidua Mill., Pinus cembra L. et Pinus uncinata Mill. Ex Mirb., dans l'étage subalpin du Briançonnais (Hautes-Alpes, France). Écologie 29:305-310. 
Plana Castellví, J. A. 1985. Estudi Climàtic i Balanç Hídric de la Conca de la Noguera Ribagorçana. Institut d'Estudis Catalans, Barcelona, Spain.

Post, E., and N. C. Stenseth. 1999. Climatic variability, plant phenology, and northern ungulates. Ecology 80:13221339.

Richter, K. 1988. Dendrochronologische und dendroklimatologische Untersuchungen an Kiefern (Pinus sp.) in Spanien. Dissertation. University of Hamburg, Hamburg, Germany.

Richter, K., and D. Eckstein. 1990. A proxy summer rainfall record for southeast Spain derived from living and historical pine trees. Dendrochronologia 8:67-82.

Rodó, X., E. Baert, and F. A. Comín. 1997. Variations in seasonal rainfall in Southern Europe during the present century: relationships with the North Atlantic Oscillation and the El Niño-Southern Oscillation. Climate Dynamics 13:275-284.

Rodríguez-Puebla, C., A. H. Encinas, and J. Sáenz. 2001. Winter precipitation over the Iberian peninsula and its relationship to circulation indices. Hydrology and Earth System Sciences 5:233-244.

Rolland, C. 1993. Tree-ring and climate relationships for $\mathrm{Abi}$ es alba in the Internal Alps. Tree-Ring Bulletin 53:1-11.

Rolland, C., R. Michalet, C. Desplanque, A. Petetin, and S. Aimé. 1999. Ecological requirements of Abies alba in the French Alps derived from dendro-ecological analysis. Journal of Vegetation Science 10:297-306.

Rolland, C., V. Petitcolas, and R. Michalet. 1998. Changes in radial tree growth for Picea abies, Larix decidua, Pinus cembra and Pinus uncinata near the alpine timberline since 1750. Trees 13:40-53.

Rolland, C., and J. F. Schueller. 1994. Relationship between mountain pine and climate in the French Pyrenees (FontRomeu) studied using the radiodensitometrical method. Pirineos 143-144:55-70.

Rolland, C., and J. F. Schueller. 1996. Dendroclimatologie du Pin à crochets (Pinus uncinata Mill. ex Mirb.) dans le Brianéonnais et le Queyras en fonction de conditions stationnelles. Schweiz. Z. Forstwes 147:351-363.

Rolland, C., and J. F. Schueller. 1998. Dendroclimatological synthesis on mountain pine (Pinus uncinata Mill. Ex Mirb.) in the Pyrenees and the Alps. Écologie 29:417-421.

Rolland, C., J. Schueller, and J. Cooper. 1995. Croissance comparée du pin à crochets et de l'épicéa (Pinus uncinata Ram. et Picea abies Karst.) sur dalle calcaire karstifiée en moyenne montagne tempérée (Vecors, France). Revue de Géographie Alpine 9:17-32.

Ruiz-Flaño, P. 1988. Dendroclimatic series of Pinus uncinata Ram. in the Central Pyrenees and in the Iberian system, Spain. A comparative study. Pirineos 132:49-64.
Schueller, J. F., and C. Rolland. 1995. Influence de l'altitude, de l'exposition et du climat sur la croissance du pin à crochet (Pinus uncinata Ram.) en Cerdagne (Pyrenées orientales françaises). Pirineos 145-146:23-34.

Stokes, M. A., and T. L. Smiley. 1968. An introduction to tree-ring dating. University of Chicago Press, Chicago, Illinois, USA.

ter Braak, C. J. F. 1987. Ordination. Pages 91-173 in R. H. Jongman, C. J. F. ter Braak, and O. F. R. van Tongeren, editors. Data analysis in community ecology. Pudoc, Wageningen, The Netherlands.

ter Braak, C. J. F. 1994. Canonical community ordination. Part 1. Basic theory and linear methods. Écoscience 1:127140.

ter Braak, C. J. F., and I. C. Prentice. 1988. A theory of gradient analysis. Advances in Ecological Research 18: 271-317.

ter Braak, C. J. F., and P. Smilauer. 1998. CANOCO reference manual and user's guide to CANOCO for Windows: software for canonical community ordination. Version 4. Microcomputer Power, Ithaca, New York, USA.

ter Braak C. J. F., and P. F. M. Verdonschot. 1995. Canonical correspondence analysis and related multivariate methods in aquatic ecology. Aquatic Science 57:255-289.

Tessier, L. 1989. Spatio-temporal analysis of climate treering relationships. New Phytologist 111:517-529.

Tessier, L., F. Guibal, and F. Schweingruber. 1997. Research strategies in dendroecology and dendroclimatology in mountain environments. Climatic Change 36:499-517.

Tranquillini, W. 1979. Physiological ecology of the alpine timberline: tree existence at high altitudes with special reference to the European Alps. Springer-Verlag, Berlin, Germany.

Ventura, J. 1992. Geomorfologia glacial de les valls de la Bonaigua, Son i els sectors occidentals de la cubeta d'Esterri d'Àneu. Pages 23-41 in La investigació al Parc Nacional d'Aigüestortes i Estany de Sant Maurici. II. Jornades sobre Recerca, Lleida, Spain.

Vigo, J., and J. Bonada. 1976. L'alta muntanya catalana: flora i vegetació. Montblanc-Martin. Barcelona, Spain.

Vigo, J., and J. M. Ninot. 1987. Los Pirineos. Pages 351384 in M. Peinado Lorca and S. Rivas Martínez, editors. La vegetación de España. Servicios Publicaciones Universidad Alcalá de Henares, Madrid, Spain.

Villalba, R., J. A. Boninsegna, T. T. Veblen, A. Shmelter, and S. Rubulis. 1997. Recent trends in tree-ring records from high elevation sites in the Andes of northern Patagonia. Climatic Change 36:425-454.

Villalba, R., T. T. Veblen, and J. Ogden. 1994. Climate influences on the growth of subalpine trees in the Colorado front range. Ecology 75:1450-1462. 